Pontifícia $_{\text {Universidade }}$ Católica $_{\text {Do Rio de Janeiro }}$

Rodrigo Nunes De Souza Trindade

\author{
Vínculos e Vulnerabilidades \\ em Psicoterapia de Família: Dois \\ Tratamentos "Fracassados"?
}

DISSERTAÇÃO DE MESTRADO

DEPARTAMENTO DE PSICOLOGIA

Programa de Pós-Graduação em Psicologia clínica 


\section{Rodrigo Nunes de Souza Trindade}

\section{Vínculos e Vulnerabilidades em psicoterapia de família: dois tratamentos "fracassados"?}

Dissertação de Mestrado

Dissertação apresentada como requisito parcial para obtenção do grau de Mestre pelo Programa de Pós-Graduação em Psicologia (Psicologia Clínica) do Departamento de Psicologia da PUCRio.

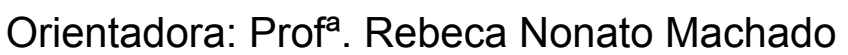


Rodrigo Nunes de Souza Trindade

\title{
Vínculos e Vulnerabilidades em psicoterapia de família: dois tratamentos "fracassados"?
}

Dissertação apresentada como requisito parcial para obtenção do grau de Mestre pelo Programa de PósGraduação em Psicologia (Psicologia Clínica) da PUCRio. Aprovada pela Comissão Examinadora abaixo.

\author{
Profa. Rebeca Nonato Machado \\ Orientadora \\ Departamento de Psicologia - PUC-Rio
}

Profa. Andrea Seixas Magalhães Departamento de Psicologia - PUC-Rio

Profa. Celia Regina Henriques Especialização em Psicoterapia de Família e Casal - CCE/ PUC-Rio 
Todos os direitos reservados. É proibida a reprodução total ou parcial do trabalho sem autorização do autor, do orientador e da universidade.

\section{Rodrigo Nunes de Souza Trindade}

Graduou-se na Universidade Federal do Rio de Janeiro em 2013. Especialização em Terapia de Família e Casal pelo CCE/PUC-Rio em 2018. Especialização em Psicologia Clínica com Crianças pelo CCE/PUC-Rio em 2018.

Ficha Catalográfica

Trindade, Rodrigo Nunes de Souza

Vínculos e vulnerabilidades em psicoterapia de família : dois tratamentos "fracassados"? / Rodrigo Nunes de Souza Trindade ; orientadora: Rebeca Nonato Machado. - 2020.

$68 \mathrm{f.}:$ il. ; $30 \mathrm{~cm}$

Dissertação (mestrado)-Pontifícia Universidade Católica do Rio de Janeiro, Departamento de Psicologia, 2020. Inclui bibliografia

1. Psicologia - Teses. 2. Psicoterapia de família. 3. Vínculos. 4. Vulnerabilidades. 5. Interrupção do tratamento. I. Machado, Rebeca Nonato. II. Pontifícia Universidade Católica do Rio de Janeiro. Departamento de Psicologia. III. Título.

CDD: 150 
Aos meus pais, minha esposa e minha orientadora, por todo o apoio e paciência. 


\section{Agradecimentos}

À minha orientadora, Rebeca Nonato Machado, por sua enorme paciência e dedicação. Agradeço por ter compreendido meu momento e por ter me motivado a continuar.

À CAPES e à PUC-Rio pela oportunidade de ter recebido uma formação gratuita e de qualidade.

Aos meus pais, que me ouviram com paciência e empatia nos momentos de dificuldade, e que tanto me incentivaram a seguir em frente.

À minha esposa, Giuliana, pela compreensão e o apoio demonstrados durante esse período difícil, e pelo amor e o carinho de todos os dias.

Ao meu irmão, Felipe, e aos amigos, pelos momentos de respiro e descontração.

Aos meus pacientes, com quem tanto aprendi durante os últimos anos.

O presente trabalho foi realizado com apoio da Coordenação de Aperfeiçoamento de Pessoal de Nível Superior - Brasil (CAPES) - Código de Financiamento 001. 


\section{Resumo}

Trindade, Rodrigo Nunes de Souza; Machado, Rebeca Nonato. Vínculos e Vulnerabilidades em Psicoterapia de Família: Dois Tratamentos "Fracassados"?. Rio de Janeiro, 2020. 68p. Dissertação de Mestrado Departamento de Psicologia, Pontifícia Universidade Católica do Rio de Janeiro.

A psicoterapia com famílias em situações de vulnerabilidade envolve muitas dificuldades, pois inclui a complexidade do trabalho com múltiplos vínculos associada às precariedades inerentes às vivências de desamparo e de violência em diferentes níveis. Visando produzir conhecimentos nesse campo, de modo a consubstanciar a prática clínica com o grupo familiar, o objetivo deste trabalho foi investigar os padrões vinculares predominantes em famílias em situações de vulnerabilidade, buscando pensar alguns dos desafios e limitações da psicoterapia de família. Para tal, foi realizada uma investigação clínicoqualitativa, a partir do método de estudo de casos, ambos interrompidos precocemente pelas famílias. Foi proposta uma análise a partir de algumas das principais contribuições psicanalíticas sobre os vínculos, dentre as quais estão as de Bion e Pichon-Rivière, além das postulações teóricas sobre a noção de duplovínculo da Teoria Sistêmica. Foi observado que os vínculos familiares eram marcados por antiemoções e situações de duplo-vínculo. Identificou-se que, por vezes, uma interrupção precoce do tratamento não significa necessariamente o fracasso da psicoterapia em família. Nos casos pesquisados, foi possível compreender que o tratamento alcançou sua função de escuta e de espaço de reflexão, dadas as limitações das qualidades dos vínculos, específicas de cada família.

\section{Palavras-Chave}

Psicoterapia de família; Vínculos; Vulnerabilidades; Interrupção do tratamento. 


\section{Abstract}

Trindade, Rodrigo Nunes de Souza; Machado, Rebeca Nonato (advisor). Linking and Vulnerabilities in Family Psychotherapy: Two "Failed" Treatments?. Rio de Janeiro, 2020. 68p. Dissertação de Mestrado Departamento de Psicologia, Pontifícia Universidade Católica do Rio de Janeiro.

Psychotherapy with families in situations of vulnerability involves many difficulties, as it includes the complexity of working with multiple links associated with the precariousness inherent to the experiences of helplessness and violence at different levels. Aiming to produce knowledge in this field, in order to substantiate clinical practice with the family group, the objective of this work was to investigate the linking patterns prevalent in families in situations of vulnerability, developing thoughts about some of the challenges and limitations of family psychotherapy. To this end, a qualitative clinical investigation was carried out, using the case study method, both interrupted early by the families. An analysis was proposed based on some of the main psychoanalytic contributions on the links, among which are those of Bion and Pichon-Rivière, in addition to the theoretical postulations on the notion of double-bind of the Systemic Theory. It was observed that family bonds were marked by anti-emotions and double-bind situations. It was found that sometimes an early interruption of treatment does not necessarily mean the failure of family psychotherapy. In the researched cases, it was possible to understand that the treatment reached its function of listening and space for reflection, given the limitations of the qualities of the links, specific to each family.

\section{Keywords}

Family psychotherapy; Links; Vulnerabilities; Interruption of treatment. 


\section{Sumário}

1. Introdução 9

2. A relação de objeto e os tipos de vinculação 13

2.1. A primeira forma de vinculação 13

2.2. A função alfa e os vínculos mais sofisticados 16

2.3. Formas variadas de vinculação 18

$\begin{array}{ll}\text { 2.4. Por que vincular-se? } & 21\end{array}$

3. Da relação de objeto à psicanálise vincular 26

3.1. O desenvolvimento a partir do outro 26

3.2. O caráter e o vínculo com o objeto interno 30

3.3. A intersubjetividade na psicanálise vincular 34

4. Estudo de casos 36

4.1. Método 36

4.1.1. Sujeitos 36

4.1.2. Procedimentos e análise dos dados 37

4.1.3. Cuidados éticos 37

4.2. Dados Clínicos 38

4.2.1. Histórico da família 1

4.2.2. Processo terapêutico da família $1 \quad 39$

4.2.3. Histórico da família 2

4.2.4. Processo terapêutico da família 2

4.3. Análise e discussão Geral $\quad 46$

4.3.1. Análise vertical da família 1

4.3.2. Análise vertical da família 2

4.3.3. Análise horizontal 54

5. Considerações finais 58

6. Referências 62

$\begin{array}{ll}\text { 7. Anexo } 1 & 66\end{array}$

$\begin{array}{lr}\text { 8. Anexo } 2 & 67\end{array}$

9. Anexo $3 \quad 68$ 


\section{1. \\ Introdução}

A teoria psicanalítica, à ocasião de seu surgimento, inaugurou o campo da psicoterapia por meio da proposta inovadora de olharmos o sujeito para além de seu sintoma, de compreendermos por meio da escuta o que há por detrás do conteúdo manifesto. Naquela época, final do século XIX, há anos os médicos deparavam-se com impasses no atendimento aos pacientes psiquiátricos e, até então, o mais próximo que haviam chegado de um tratamento eficaz tinha sido a hipnose. Freud, contudo, não buscou uma alternativa imediatamente; primeiro tentou trabalhar com o pensamento hegemônico e, somente então, percebendo limitações - dele próprio e do método de Charcot -, ousou debruçar-se de maneira interessada sobre o que seus pacientes tinham a dizer (Gay, 2012).

A partir desse ponto, Freud permitiu-se também pensar criativamente sobre o que escutava, valendo-se de seu grande repertório cultural e literário para interpretar os aspectos do funcionamento psíquico que conseguia identificar. Assim nasceram suas primeiras hipóteses, as quais foram desenvolvidas e lapidadas ao longo de anos de publicações, correspondências, críticas e reformulações, culminando na proposição de modelos pretendidos universais, mas que, de forma paradoxal, permitiam lançar luz sobre a singularidade. Para além das importantes proposições teóricas e clínicas, a maior contribuição freudiana talvez tenha sido o exemplo deixado pelo autor em termos da ousadia em pensar criativamente a realidade psíquica do sujeito, muitas vezes estranha a si próprio.

Segundo Gay (2012), nos anos seguintes houve um expressivo aumento do número de colaboradores dentro do movimento psicanalítico e uma mudança radical de paradigma, que alçou a inovadora teoria freudiana a um patamar mais elevado no campo da saúde mental. Curiosamente, novos desafios clínicos foram sendo percebidos e, então, foi a vez de outros psicanalistas ousarem pensar de maneira inovadora, não com a pretensão de refutar as postulações de Freud, mas com o objetivo de alcançar pontos que sua teoria não esgotava. Foi o caso de Melanie Klein (1932), com a psicanálise de crianças e outros trabalhos, de autores como Fairbairn (1952), Bion (1962) e Balint (1968), com suas proposições sobre as relações objetais e os vínculos, e de Winnicott (1945), com a noção de transicionalidade entre outras contribuições notáveis. 
Esses autores abriram ainda mais as reflexões do campo psicanalítico, fornecendo bases teóricas, por exemplo, para que Pichon-Rivière (1980) e os que se seguiram fossem além em suas contribuições acerca do processo de vinculação. Neste caminho, criou-se uma psicanálise relacional, mais preocupada com o que se produz no encontro entre dois sujeitos, do que com os fenômenos intrapsíquicos, tão caros à psicanálise clássica. Contudo, é interessante pensarmos que, mesmo afastando-se da fonte primária ao longo do tempo, a visão da psicanálise vincular não se opôs à da clássica, apenas ofereceu uma outra metodologia de trabalho, que não invalidava a anterior, mas recepcionava ou adaptava muitas de suas premissas. Nada mais era, portanto, que uma ramificação orgânica da teoria original que buscou endereçar criativamente as questões para as quais o pensamento hegemônico não estava preparado, originando a clínica com casais e famílias no campo psicanalítico.

Atualmente, nesse sentido, uma vez mais somos convocados por desafios encontrados na clínica de nosso tempo a conquistarmos a herança oferecida por nossos antecessores teóricos e a expandirmos as reflexões teórico-clínicas de maneira renovadora. A intenção com esse estudo é ampliar a compreensão sobre um dos aspectos mais relevantes da clínica com famílias: os vínculos. Há, contudo, um desafio intrínseco a tal conceito, dadas as diferentes línguas em que foi descrito e as traduções possíveis. Bion utilizou "linking", que poderia ser traduzido como ligação; Bowlby fez uso da palavra "bonding", que entendemos como apego; Bateson valeu-se do termo "double- bind", que foi traduzido como duplo-vínculo. Entretanto a palavra vínculo só veio a ser publicada anos depois, por Pichon-Rivière, e posteriormente traduzido para o inglês como "linking". Para os fins a que se destina este trabalho, contudo, não faremos distinções etimológicas de tais termos, tal como argumentado por Ogden (1986). Da mesma forma, dois outros termos discutidos neste trabalho, ego e self, que muitas vezes foram concebidos por diferentes perspectivas e teorizações na psicanalise, não serão considerados distintos, tal como ocorre na obra de Klein.

Sendo assim, definimos como objetivo geral investigarmos os padrões vinculares predominantes em famílias em situações de vulnerabilidade, buscando pensar alguns dos desafios e limitações da psicoterapia de família. Nesse sentido, estabelecemos como objetivos específicos estudarmos diferentes contribuições acerca da noção de vínculo a partir de diferentes autores da teoria psicanalítica e 
da teoria sistêmica, e investigarmos as características das configurações vinculares de famílias em situações de vulnerabilidade.

Visando atingirmos tais objetivos, estudamos algumas contribuições fundadoras da teoria das relações de objeto, como as de Klein (1932), Fairbairn (1952) e Balint (1968), as quais entendemos como propostas de base para pensarmos os vínculos. Em seguida, percorremos diferentes contribuições sobre o vínculo propostas por Bion (1962), Pichon-Rivière (1980), e Puget \& Berenstein (1993), que nos permitiram ampliar nossa compreensão sobre as diferentes dimensões do fenômeno vincular. Além disso, acrescentamos alguns comentários de Bateson et al. (1956), Watzlawick et al. (1967) e Elkaïn (1989) à noção de duplo-vínculo da Teoria Sistêmica, uma possibilidade de vinculação promotora de adoecimento, o que consistiu em um complemento importante à nossa exploração. Buscamos colocar todas essas teorias em perspectiva como igualmente relevantes para a construção de uma noção mais completa acerca do fenômeno, articulandoas de modo a obter um eixo coeso de reflexão.

Por último, estudamos dois casos clínicos atendidos pelo pesquisador no Serviço de Psicologia Aplicada da Pontifícia Universidade Católica do Rio de Janeiro (SPA - PUC-Rio), enquanto aluno do curso de especialização em Psicoterapia de Família e Casal. Ambos se referem a atendimentos de família em situação de vulnerabilidade, escolhidos em razão de terem sido encerrados de maneira precoce e por terem apresentado muito claramente ataques ao vínculo terapêutico, cada uma delas com uma configuração e dados socioeconômicos distintos. Essa característica poderia ter-nos levado a compreendermos como fracassados os trabalhos realizados, mas nossa análise nos conduziu ao entendimento de que, em ambos os casos, a psicoterapia alcançou sua função de escuta. Ela respeitou as limitações de cada família quanto à sua disponibilidade ao autoconhecimento à época dos atendimentos. Mais importante ainda, vimos que o vínculo com os coterapeutas não pareceu ter sido abalado pelas decisões das famílias de interromperem o trabalho clínico, denotando uma relativa independência entre o vínculo terapêutico e o vínculo com o terapeuta.

Acreditamos que as desistências ocorram em razão da complexidade da psicoterapia com famílias, a qual permite evidenciar no setting as diferentes expressões dos vínculos estabelecidos entre os membros do grupo familiar (Puget, 2015). Sobretudo, quando tal modalidade clínica acolhe famílias em situações de 
vulnerabilidade, evidenciamos o desamparo e a violência como marcas fundamentais no tratamento (Broide, 2010), exigindo do terapeuta uma atenção ainda maior aos impasses e um ativo exercício de sua função continente (Zimerman, 2010). Entendemos, portanto, que este estudo é relevante devido ao enfoque dado aos vínculos em tratamentos de grupos familiares, face a contextos de vulnerabilidade, buscando desenvolver recursos clínicos para consubstanciar uma prática psicoterapêutica continente e transformadora. 
2.

\section{A relação de objeto e os tipos de vinculação}

Com o objetivo de pensarmos a noção de vínculo e os processos de vinculação a partir da literatura psicanalítica, discutimos neste capítulo algumas contribuições relevantes à teoria das relações objetais, a qual pode ser entendida como o domínio da psicanálise que alicerça os estudos sobre a intersubjetividade. Antes dela, interessava aos psicanalistas compreenderem os processos intrapsíquicos, tais como a influência das tensões pulsionais e do conflito edípico sobre o psiquismo individual, relegando o objeto a um lugar secundário. $\mathrm{Na}$ perspectiva das relações objetais, diferentemente, a cada nova contribuição a relação estabelecida entre o self e o objeto ia ganhando destaque e, com ele, a possibilidade de falarmos em uma "relação".

Foi com Melanie Klein que essa mudança de paradigma começou a ser construída. A autora, instigada pela dinâmica do menino com o carretel descrita por Freud (1920) - o "fort-da" -, postulou que o brincar da criança seria análogo à associação livre do adulto, podendo então auxiliar na elaboração dos conflitos infantis. Suas ideias causaram grande controvérsia no meio psicanalítico, pois a conclusão lógica a partir desse raciocínio era a de que a criança, mesmo tendo menos recursos verbais que o adulto, poderia se beneficiar de um trabalho de análise por meio de uma interpretação sistemática do seu brincar (Segal, 1964).

Tal como Freud no tocante ao complexo de édipo, Klein se deteve no aspecto pulsional em detrimento do relacional (Ogden, 1986). Contudo, em razão de ter sido a pioneira em discorrer sobre as relações entre self e objeto nos primórdios da vida mental, pensamos ser de grande importância nos debruçarmos sobre alguns tópicos relevantes de sua obra, os quais consideramos fundamentais para compreendermos as futuras postulações sobre vínculo no campo das relações de objeto.

\section{1.}

\section{A primeira forma de vinculação}

Indo por esse caminho, segundo Ogden, na literatura kleiniana o self da criança seria, inicialmente, um self-objeto (Ogden, 1986). Isso significa, segundo o autor, que em um momento anterior à subjetividade e ao próprio pensamento 
verbal, o self estaria vulnerável à atuação implacável da pulsão de morte, existindo apenas enquanto objeto desta.

Assim, poder-se-ia dizer que o movimento pulsional criaria um "sentido de perigo [anterior], que receberia forma específica [apenas] quando o bebê organizasse suas percepções" (Ogden, 1986, p.41). Isso ocorreria em razão da prevalência da pulsão de morte sobre a pulsão de vida, que, segundo o pensamento da autora, contaminaria o self e também os objetos.

Nesse sentido, tanto a introjeção de objetos bons quanto a projeção de objetos maus ajudariam a atenuar o caos do mundo interno. $\mathrm{O}$ mecanismo projetivo, de acordo com Segal (1964), permite à criança lançar os objetos maus para fora, em sua fantasia onipotente, de modo que possa, a partir de então, não apenas ver seu mundo interno livre deles, como rejeitá-los e atacá-los sem pôr em risco o self. Ambos os mecanismos, a projeção e a introjeção, são, para Klein (1946), recursos defensivos característicos do que chamou posição esquizoparanóide, uma forma de organização primitiva da vida mental, na qual ocorre a cisão do objeto em suas formas parciais - bom e mau - e uma correspondente cisão do self. Desta forma, o self amoroso poderia se relacionar com o objeto bom, sem ser contaminado pelo self odioso, que pode então se relacionar com o objeto mau. Tal processo, possibilitado pelo mecanismo de cisão, permite que ambas as experiências de amar e de odiar possam acontecer de forma independente, permitindo a sobrevivência do self ao conflito pulsional (Ogden, 1986).

Neste momento inicial do funcionamento psíquico, a integração dos objetos parciais poderia ser extremamente perigosa, pois provocaria a reunião de afetos opostos dirigidos a um mesmo objeto total - fenômeno conhecido como ambivalência -, de quem a criança depende para sobreviver. Por esta razão, são tão importantes os recursos de projeção, introjeção, negação e cisão, bem como o da identificação projetiva - mecanismo descrito pela primeira vez por Klein (1946) e aprofundado por Bion (1967) -, como formas de proteger o self.

Nesse contexto, dentre os recursos utilizados no âmbito da fantasia onipotente do bebê, segundo Ogden (1986), a identificação projetiva é a formação defensiva que apresenta um componente interpessoal, para além da simples projeção, uma vez que pressupõe a manutenção de um controle onipotente, na fantasia, sobre aquilo que foi projetado. Trata-se de um dispositivo que precisa, 
portanto, da "cooperação" do outro, ou seja, que este permita-se ser capturado e, então, passe a encarnar o objeto parcial na relação com o sujeito. No caso do bebê, esta pessoa é a mãe ou quem exerça tal função.

O mecanismo de identificação projetiva usado pelo bebê permite à mãe ter acesso ao estado emocional de seu filho, munindo-a de recursos para dar-lhe a contenção e a tradução necessárias para suas sensações e sentimentos. Bion (1967), portanto, propõe que se pense o conceito para além da ideia kleiniana de um mecanismo defensivo, apontando que também pode ser utilizado como recurso emocional primitivo de comunicação e uma forma mais básica de vinculação, posto que estabelece uma ligação com o outro baseada na fantasia de controle sobre os objetos neste projetados.

Acerca dessa última possibilidade, o autor explica que no tratamento de pacientes psicóticos, por vezes, a identificação projetiva é a única forma de vinculação possível, tornando-se a maneira pela qual o paciente pode beneficiar-se da situação intersubjetiva analítica (Bion, 1967). À medida que cinde e afasta as partes da psique das quais precisa livrar-se, o paciente projeta-as no analista, onde podem permanecer, em fantasia, sob relativo "controle", sem que sejam perdidas ou reintrojetadas.

Segundo Bion (1962), tanto a identificação projetiva quanto os tipos vinculares mais sofisticados, que se formam a partir dela no curso do desenvolvimento, apresentam uma característica fundamental em comum, a qual nomeou relação continente-conteúdo. Na relação mãe-bebê, o bebê comporta-se como conteúdo ao procurar saciar sua fome, enquanto o seio da mãe - o qual contém a solução para a demanda - comporta-se como continente, sendo capaz de mitigar a angústia. Trata-se, portanto, de uma relação de objeto caracterizada pela complementariedade e essencial à própria sobrevivência do lactente, cujas características impactam de maneira significativa a qualidade de vida do sujeito (Zimerman, 2010; Ávila, 2016).

Nesta mesma linha de pensamento, Bleichmar \& Bleichmar (1992) também tratam a identificação projetiva como base para a empatia e para a comunicação entre as pessoas. Segundo os autores, à medida em que aspectos bons ou maus do self são projetados sobre o objeto, estes o afetam e, assim, levam-no a sentir-se de maneira diretamente relacionada ao teor do que foi projetado. Dito de outro modo, se o bebê projeta em sua mãe os objetos maus, esta 
poderá sentir-se desprezada, frustrada, perseguida, tal como o filho diante daquelas ameaças fantasmáticas. Assim, a mãe teria acesso ao que o bebê está sentindo e, se puder interpretá-lo desta forma, poderá traduzir o conteúdo de suas projeções.

\section{2 .}

\section{A função alfa e os vínculos mais sofisticados}

Nesse sentido, a partir do referencial bioniano (1967) é possível dizer que a primeira experiência vincular ocorre em um cenário, no qual uma mãe (ou um outro significativo) atende ao choro de seu bebê. A demanda feita pelo bebê seria, a princípio, desconhecida de ambos, mas eventualmente a mãe conseguiria interpretá-la, nomeá-la e solucioná-la, dando fim às lágrimas do filho. Nesse exemplo está expressa a ideia bioniana de que, na primeira infância, a mãe deve exercer a função de tradução dos elementos beta - conteúdos em estado bruto aos quais tem acesso por meio da identificação projetiva do bebê (Bion, 1967; Zimerman, 2010; Braga, 2017). Através de sua capacidade de rêverie, ou de "sonhar a dois", a mãe transformaria os elementos beta em alfa, deixando-os mais seguros de serem reintrojetados pelo bebê, e assim desenvolveria condições internas no filho de conhecer e reconhecer as próprias necessidades, demandas e experiências emocionais. Nesse processo de sonhar a dois, a mãe entra em um estado de íntima sintonia com o bebê, a partir do qual se permite ser afetada pela comunicação primitiva do filho sem confundir-se com aquilo que nela for projetado (Bion, 1967). Esta possibilidade de tradução dos elementos beta em alfa, por sua vez, ficou conhecida como função alfa.

Essa noção é sustentada pela teorização bioniana $(1962 ; 1967)$ acerca de três modalidades de vínculos por ele identificadas: a do amor (L), a do ódio $(H)$ e a do conhecimento $(K)$, cada uma podendo ser vista em suas formas positiva $(+)$ e negativa (-) - a emoção e a antiemoção. Nessa perspectiva, Zimerman (2010) reconhece como valiosas as contribuições bionianas e propõe que sejam acrescentadas outras duas formas vinculares, relativas ao que chamou de vínculo pelo reconhecimento: $+\mathrm{R}$ e $-\mathrm{R}$.

Segundo Bion (1962), o vínculo pelo amor teria em $+\mathrm{L}$ a possibilidade de expressão direta do amor, enquanto -L representaria formações reativas contra um 
ódio subjacente, como por exemplo o puritanismo ou um pseudoaltruísmo. Nesse sentido, Zimerman (2010) ilustra descrevendo o caso de uma mãe superprotetora que ama seu filho de forma simbiótica, possessiva e sufocante, impedindo a individuação dele. Assim, pode-se pensar no estabelecimento de um vínculo de antiamor (-L) enquanto promotor de culpa, que pressupõe sacrifícios e renúncias da singularidade.

O vínculo pelo ódio, segundo Bion (1962), teria em $+\mathrm{H}$ a possibilidade de o sujeito dar-se conta dessa experiência emocional e de expressar o ódio de maneira direta, o que se torna possível somente a partir da experiência de sobrevivência do objeto após ataques feitos a ele na fantasia (Winnicott, 1969). Por outro lado, o antiódio (-H) deve ser entendido como uma emoção latente, escondida às sombras de uma atitude supostamente amorosa, que não pode ser expressa de forma direta ou mesmo sentida por seu portador. Trata-se de um padrão vincular no qual atos violentos são cometidos e justificados em nome do "amor", o que alude a uma forma de vínculo impregnado de ódio, porém perversamente defendido.

Por sua vez, proposto por Bion (1967), +K seria uma espécie de vínculo que se colocaria entre um sujeito que deseja conhecer e um objeto que consente ser conhecido, tornando-se, portanto, um componente essencial à psicoterapia. Quando, contudo, há uma falha na capacidade de rêverie materna e o bebê não consegue introjetar a função de conhecimento sob a forma de elementos alfa, o que ocorre é a reintrojeção da angústia projetada na forma de elementos beta, gerando uma intolerável vivência de desespero (Zimerman, 2010; Braga, 2017). A partir de então, segundo Bion (1967), ocorre um aumento na força das identificações projetivas como uma tentativa, por parte do bebê, de encontrar um objeto continente, o que acaba retroalimentando um ciclo vicioso. Assim, visando a interrupção desse angustiante circuito promovido pelo registro da frustração associado à experiência de conhecimento, o sujeito responderia com anticonhecimento (-K), uma espécie de recusa a conhecer, cuja expressão é reconhecida na atitude de ataque ao vínculo (attacks on linking).

Por último, Zimerman (2010) defende que o vínculo também seja pensado a partir do reconhecimento, o qual pode ocorrer de quatro formas: pela necessidade do reconhecimento, por parte do sujeito, do funcionamento de sua própria psique; pela possibilidade do reconhecimento do outro em sua alteridade; 
pelo reconhecimento (ou gratidão) ao outro; e pela necessidade de ser reconhecido pelos outros em suas capacidades. Esses modelos de reconhecimento também podem ser expressos de maneira positiva (emoção) ou negativa (antiemoção), implicando respectivamente na segurança baseada na compreensão, pelo sujeito, de seu lugar no mundo e na instabilidade associada às distorções nas percepções de si mesmo e dos outros.

\section{3.}

\section{Formas variadas de vinculação}

Pensando, portanto, nas quatro modalidades vinculares descritas em sua observância à ideia fundamental da relação continente-conteúdo (Bion, 1962), há sempre uma demanda sendo endereçada a algo ou alguém que deve atendê-la. Essa dinâmica faz dos vínculos canais privilegiados de comunicação, cujas mensagens impregnadas de elementos beta exigem do interlocutor um esforço psíquico de tradução, análogo ao da mãe de posse de sua função alfa.

No campo da psicoterapia de família, houve uma discussão que se aproximou dessas compreensões, as quais entrelaçaram a necessidade de simbolização e de tradução dos afetos para o estabelecimento da qualidade dos vínculos. Apesar de posições conceituais distintas, as contribuições de Watzlawick et al. (1967) sobre duplo-vínculo (Double-Bind) enriquecem nossa reflexão sobre as modalidades vinculares e suas repercussões na interação entre os membros de uma família. Segundo os autores, existem dois níveis na comunicação humana: o analógico, representado pela linguagem não-verbal, e o digital, que equivale à linguagem verbal. Por haver apenas dois níveis, só é possível traduzir um por meio do outro, condição que traz desafios porque nem sempre existe uma correspondência exata entre os elementos presentes nos dois códigos.

De acordo com Watzlawick et al. (1967), a interpretação dos sonhos descrita por Freud em 1900 seria um oportuno exemplo de tentativa de tradução da linguagem analógica do material onírico para a linguagem digital, utilizando-se para isso um raciocínio que envolve o reconhecimento dos mecanismos de deslocamento e condensação. Desse modo, da mesma forma que é impossível um esgotamento da compreensão dos conteúdos latentes de um sonho, também, é 
inviável conhecermos por completo as nuances dos padrões comunicacionais (Guimarães et al. 2017). Sendo assim, na perspectiva da comunicação humana, um dos motivos para a presença de conflitos na comunicação entre os sujeitos seria a ocorrência de "perdas" ou falhas inerentes às tentativas de tradução (Watzlawick et al., 1967).

Pensando nos erros de tradução ocorrido nas interações humanas, Bateson \& Jackson (1964) propuseram a hipótese de que haveria uma relação entre formação de sintomas psiconeuróticos e as dificuldades na tradução da linguagem analógica em digital. Segundo os autores, na impossibilidade da "digitalização" do conteúdo inconsciente, que, em Freud (1893), seria como trazer à consciência o material reprimido insuportável, restaria a linguagem analógica como via de expressão: a conversão histérica, por exemplo.

Anos antes, Bateson et al. (1956) já haviam formulado a ideia do duplovínculo, representando uma situação complexa em que as comunicações analógica e digital formam um par antitético, capaz de produzir uma linguagem paradoxal. Segundo os autores, existindo a confluência de outros fatores como o caráter vital da relação, a impossibilidade de o sujeito deixar o campo, a ameaça de uma punição e a repetição cíclica da experiência, teríamos, segundo os autores, um padrão comunicacional psicotizante. Nesses casos o sujeito seria levado a questionar a própria confiabilidade de sua percepção da realidade, passando a perceber o ambiente por meio de um padrão duplo-vincular. Assim, posteriormente, a mera exposição a qualquer etapa do duplo vínculo poderia levar a pessoa a sentimentos de pânico ou fúria.

Há, nesse sentido, duas situações interessantes da expressão duplovincular. A primeira pode ser exemplificada por meio de uma cena onde uma mãe esbraveja com sua filha menor de idade, cobrando-lhe pelo fato de não ser suficientemente afetuosa e exigindo que a filha seja mais carinhosa. Contudo, faz a demanda em tom agressivo, verbalizando em ritmo acelerado, com a postura inclinada para frente como um animal pronto a atacar. Nessa situação, a criança recebe duas mensagens: (1) minha mãe quer que eu a abrace, e (2) minha mãe não quer que eu a abrace. Esse arranjo tende a tornar-se desesperador para a criança, posto que as duas demandas são mutuamente excludentes, ou seja, seria impossível atender a uma sem obrigatoriamente desatender a outra. Tampouco a menina poderia deixar o campo, considerada sua condição de menor de idade e da 
importância vital do vínculo com a mãe. Assim, observando a repetição cíclica desse padrão ao longo do tempo, teremos presentes todas as condições do duplovínculo.

A segunda situação é a que Elkaïn (1989) chamou de duplo-vínculo recíproco. Trata-se de um funcionamento vincular em que duas pessoas colocam uma à outra em situação duplo-vincular, de modo que a própria relação torna-se perigosamente adoecedora. Nesse contexto, na medida em que permite a cada um dos sujeitos reviver na relação experiências primitivas de prazer e frustração, o vínculo mantém ambos aprisionados em repetições cíclicas que tenderiam a intensificar os conflitos. $\mathrm{O}$ autor oferece o exemplo de uma esposa que se queixa da ausência do marido, enquanto ele desejava ser reconhecido pela esposa. Com base em suas experiências primitivas, contudo, ela tinha a convicção inconsciente de que seria inevitavelmente abandonada, ao passo que ele tinha certeza de que seria rejeitado, independentemente do quanto se esforçassem. "Assim, cada um dos membros estava partido pela contradição entre seus dois níveis de expectativa" (Elkaïn, 1989, p.24).

O que se seguia era que a esposa pedia ao marido que se aproximasse, mas quando ele vinha, esta recusava a aproximação alegando sentir-se espionada. Quando ele se afastava, no entanto, ela se queixava de seu distanciamento. Isso ocorria, segundo Elkaïn (1989), porque nessa situação, ambos os níveis de expectativa eram atendidos e frustrados alternadamente, levando-a a uma situação de grande desconforto. Pelo lado do marido, sua intenção de ser reconhecido era atendida quando a esposa se queixava, entendendo se tratar de uma demanda por sua aproximação. Entretanto, quando ela o afastava ou meramente o excluía, dando atenção a terceiros, o atendia em sua expectativa de rejeição, frustrando-o em sua necessidade de aceitação. Assim, a complementariedade entre eles tornava o campo inescapável, e a repetição do ciclo duplo-vincular recíproco extremamente angustiante.

A noção de duplo-vínculo trouxe-nos, portanto, a possibilidade falarmos em uma vinculação promotora de sofrimento, algo que podemos identificar também na teoria psicanalítica de Balint (1968) a partir da ideia de falha básica: “a passagem traumática [porém constitutiva] da situação originária de harmonia para a constituição mais definitiva dos objetos" (Peixoto Junior, 2004, p.242). Segundo o autor, a falha básica se faz no desencaixe entre a demanda de amor do 
sujeito e a disponibilidade do meio em atendê-lo, constituindo-se em uma "ferida que eventualmente pode cicatrizar, mas que não pode de modo algum ser suprimida" (Peixoto Junior, 2004, p.243).

Nesse contexto, Balint (1968) fala de duas formas extremas de subjetivação oriundas da falha básica que tenderiam a não formar vínculos verdadeiros, dado o grau de desconfiança no mundo dos objetos. São eles: a ocnofilia - na qual o sujeito sente-se inseguro sem a presença do objeto, temendo o espaço entre eles e buscando tranquilidade na adesão aos mesmos - e o filobatismo - no qual "as expansões sem objeto (...) são consideradas como seguras e amistosas, enquanto os objetos são percebidos como perigos traiçoeiros e empecilhos à satisfação" (Peixoto Junior, 2004, p.238). Clinicamente, segundo Mello \& Herzog (2008), o ocnofílico traria consigo uma sensação de culpa por não conseguir atrair a atenção do objeto, responsabilizando-se pela falha e passando a desconfiar de suas potencialidades. O filobata, por sua vez, falaria de um sentimento de que o meio lhe nega cuidados intencionalmente, produzindo uma posição subjetiva de suspeita em relação aos objetos (Mello \& Herzog, 2008).

Segundo Balint (1968), ambos - o filobata e o ocnofílico - buscam reaver o estado de mistura harmoniosa da primeira infância, minimizando o perigo do encontro com o objeto, restando a eles, por vezes, a satisfação autoerótica pela impossibilidade de gratificação no mundo dos objetos. Isso nos levaria a ideia de que, segundo Balint, "todo narcisismo é secundário ao investimento objetal original, (...) [constituindo-se como] uma espécie de simulação da doação que não existiu" (Mello \& Herzog, 2008, p.1133), diferença importante em relação ao narcisismo freudiano. Assim, considerados os desdobramentos patológicos de uma vinculação adoecedora ou demasiadamente frágil, torna-se oportuna a indagação acerca do por quê o sujeito busca o vínculo.

\section{4}

\section{Por que vincular-se?}

Encontramos as primeiras proposições interessantes sobre a essencialidade da vinculação na obra de Ronald Fairbairn, o qual, da mesma forma que Freud e Klein, conferiu grande importância à dinâmica pulsional, embora tenha diferido 
destes ao afirmar que o objetivo da libido não seria meramente a descarga de tensão, e sim a busca pelo objeto (Celes et al. 2006). Isso porque, segundo Fairbairn (1952), o bebê não teria condições de sobreviver sozinho, necessitando de um objeto a quem pudesse vincular-se, de modo a garantir os cuidados que lhe permitirão viver. De acordo com ele, qualquer objeto serviria para uma mera descarga de tensão em termos quantitativos, mas o mesmo não se verificaria no caso do vínculo, objetivo último da pulsão de vida. Nessa situação o objeto deve ter características específicas que permitam ao self vincular-se.

Na perspectiva de Fairbairn, “apenas através de relações objetais externas satisfatórias, que cumpram um papel estruturante para a personalidade (...), é possível o amadurecimento do ego" (Nunes e Peixoto Junior, 2019). Com efeito, a perda deste único objeto primordial - comumente a mãe ou quem exerça tal função - seria particularmente desoladora para o self primitivo, diferentemente do que ocorreria com o self mais maduro, o qual ainda poderia contar com outros objetos ou eventualmente substituir aquele que foi perdido. Contudo, caso a relação estabelecida com objetos externos não seja satisfatória, haveria, segundo Nunes \& Peixoto Junior (2019), a criação de objetos internos de caráter compensatório.

Aqui vale ressaltar a semelhança entre a ideia presente no termo "satisfatória" e àquela contida na expressão "suficientemente boa" em Winnicott (1967), que pressupõe a impossibilidade de uma maternagem perfeita, mas que atenda razoavelmente ao que se espera dela. Podemos observar, inclusive, que além de Fairbairn (1952) e Winnicott (1967), Klein (1946) e Balint (1968) também concordam com a noção de que o outro significativo para o bebê virá necessariamente a falhar, sendo importante a ocorrência de frustrações para que o desenvolvimento psíquico siga seu curso. Uma ressalva, contudo, com a qual todos esses autores parecem concordar, é a de que essa falta - ou falha - não deve ser maior do que a capacidade da criança em tolerá-la, sob o risco de provocar o surgimento de psicopatologias graves.

Em Fairbairn (1952) isso fica evidente pela compreensão de que, dada a natureza relacional do self, este viria a perder "o sentido caso não estivesse ligado a algum objeto, correndo inclusive o risco de parar de existir" (Nunes \& Peixoto Junior, 2019, p.76). Dessa forma, é coerente que, dentro de sua teorização, Fairbairn proponha um caminhar do desenvolvimento em direção à uma 
"dependência madura" - ou "rumo à independência", em Winnicott (1963a) -, ao invés de pensar em independência. Essa teorização propõe um desenvolvimento que busque o estabelecimento de vínculos mais numerosos e elaborados, os quais possuam a inerente condição de uma relativa dependência. Isso, contudo, dependeria do estabelecimento de relações satisfatórias com objetos externos, ou seja, em uma situação em que tanto sujeito quanto objeto apresentem-se diferenciados (Nunes \& Peixoto Junior, 2019).

Nesse sentido, compreendendo a importância do vínculo para o desenvolvimento e a própria existência do ser humano, Fairbairn (1952) demonstrou, por meio de relatos clínicos, o fenômeno da lealdade ao objeto interno mau, relacionando-o a uma "convicção inconsciente de que um objeto mau é preferível a nenhum objeto" (Ogden, 1986, p.163). Isso nos permite compreender que, segundo Fairbairn, a sobrevivência do sujeito está relacionada à manutenção do vínculo com os objetos, justificando assim que se procure preservar o vínculo a qualquer preço, mesmo que seja com o objeto mau - externo ou interno.

Por sua vez, não muito distante dessa linha de raciocínio podemos situar as ideias de Michael Balint, em cuja teorização a subjetividade é colocada como produto da interação íntima entre o sujeito e o meio. Segundo o autor, "no princípio, trata-se de uma interdependência amorosa entre o recém-nascido e o entorno, na maior parte das vezes encarnado na figura da mãe" (Mello \& Herzog, 2008 , p.1124). No vocabulário balintiano, contudo, falar em amor é como falar em relação de objeto, e, portanto, não exclui a possibilidade de aparecimento do ódio.

A situação de interdependência referida pelo autor nos é particularmente interessante, pois assemelha-se ao estado de preocupação materna primária, descrito por Winnicott (1963a), e à capacidade de rêverie, postulada por Bion (1967). Segundo Balint (1968), a ideia denota que tanto o bebê depende da mãe quanto esta depende dele, formando uma relação onde cada um procura satisfazerse por meio do outro, sem qualquer responsabilidade de retribuição. Winnicott (1963a), de sua parte, definiu a preocupação materna primária como um estado de devoção da mãe que a leva ao estabelecimento de uma condição recíproca de dependência absoluta entre ela e o bebê. Ali, segundo ele, seria produzido um estado alterado de consciência pela identificação da mãe com o bebê, que a 
tornaria capaz de traduzir o estado de espírito do filho; de transformar elementos beta em alfa, de acordo com Bion (1967).

Um exemplo interessante sobre essa reciprocidade é dado por Zimerman (2010), o qual declara que a mãe costuma ser tão afetada pelo vínculo quanto o próprio bebê. Mencionando Winnicott (1967), ele fala da importância do olhar materno enquanto espelho para o recém-nascido, mecanismo pelo qual o bebê pode ter certeza de sua própria existência, enquanto a mulher observa, no filho, o reconhecimento de seu bom desempenho como mãe. Segundo Zimerman (2010), nos casos em que o bebê apresenta respostas fisiológicas como por exemplo, a mãe pode ser tomada de uma fantasia de não ser amada por seu bebê, tornando-se incapaz de garantir ao bebê o seu lugar e sua existência. Isso poderia lançar o vínculo num ciclo angustiante que se retroalimentaria.

A diferença, em Balint (1968), está na premissa de que à medida em que existe uma coincidência entre os desejos da mãe e do bebê, e cada um procura satisfazer-se no outro, cria-se uma situação de satisfação mútua - embora não haja o compromisso da reciprocidade - e de interdependência. Contudo, pelo fato de o bebê se encontrar em uma situação de grande imaturidade e dependência em relação aos cuidados primários, o "objeto cuidador" é quem precisa se adaptar às necessidades do primeiro. Segundo Mello e Herzog (2008), essa seria, contudo, uma adaptação prazerosa.

Nesse sentido, podemos dizer que, para o Balint,

"o amor de objeto primário, isto é, os primeiros vínculos afetivos do indivíduo com os objetos primordiais correspondem ao desejo de ser amado sem restrições; desejo que advém da dependência do bebê humano de outrem para se constituir e sobreviver. Pode situar-se como correlata dessa dependência outra característica essencial do amor primário, a saber, a 'tendência a agarrar-se' (...) busca por proximidade.” (Mello \& Herzog, 2008, p.1125).

Segundo Balint (1968), portanto, o que chamou de amor primário representa a convergência entre o desejo de ser amado, por parte do bebê, e a disponibilidade afetiva a amá-lo, por parte da mãe. Para o autor, não há experiência de onipotência, posto que não existe a necessidade de qualquer 
esforço, por parte do bebê, em provocar na mãe a resposta que deseja; a alteridade já existiria nesse contexto, mas tenderia à invisibilidade, até que a falta o fizesse presente. Como exemplo, Balint (1968) comparou essa situação primordial de mistura entre mãe e bebê à relação entre um organismo e o ar: não se confundem, contudo, a presença do ar passará despercebida até que este falte. Caso seu suprimento de ar seja suficiente, o organismo tenderia a encará-lo como parte de si.

O recém-nascido, portanto, adentraria o mundo das substâncias - onde predominam as sensações como o calor, o ritmo, os odores, etc. -, em oposição ao mundo dos objetos - a partir do qual surge a alteridade -, vindo a conhecer este último apenas quando ocorrem falhas na experiência de amor primário. A possibilidade do amor adulto seria, nesse contexto, a passagem do amor primário, no qual o sujeito é passivo, para uma experiência ativa em que o sujeito busca o objeto para satisfazer-se. Deste modo, vínculos com a alteridade seriam formados de modo a tentar, por meio deles, recuperar a experiência de mistura harmoniosa com o entorno presente no início da vida (Mello \& Herzog, 2008).

Temos, portanto, segundo Balint (1968), que o objetivo da libido seria a restauração ou preservação da harmonia original, sendo o amor primário o protótipo das futuras vinculações aos objetos, na medida em que gera essa demanda de amor passivo. Nesse sentido, a própria formação de um casal seria uma "adaptação mútua dos amantes", no sentido se promoverem satisfação mutuamente em troca de sentirem-se satisfeitos, em uma espécie de cooperação (Mello \& Herzog, 2008). 


\section{3.}

\section{Da relação de objeto à psicanálise vincular}

Ao caminharmos pelo capítulo anterior, pudemos constatar que o vínculo parece ter caráter vital, ao ponto de ser preferível que se estabeleça entre o self e o objeto mau à não haver nenhum vínculo, como proposto por Fairbairn. Nessa mesma linha, vimos que o sujeito busca resgatar o estado de mistura harmoniosa da primeira experiência vincular, de acordo com Balint, mas que dependendo de como se desenvolve a experiência que chamou de falha básica, falsos vínculos podem surgir como forma de mitigar a angústia. Assim percorremos as noções de ocnofilia e filobatismo, bem como a ideia de duplo-vínculo, enquanto representantes de vinculações adoecidas ou promotoras de adoecimento.

Vimos também a ideia bioniana de a identificação projetiva funcionar como a primeira e, em alguns casos, única forma possível de vinculação, podendo ser encontrada durante o momento de mistura harmoniosa entre mãe e filho. E que poderá servir de base para as formas mais sofisticadas de vinculação, tais como aquelas baseadas nas emoções e antiemoções propostas por Bion e Zimerman. Entendemos que essas são postulações fundamentais para pensarmos o vínculo, sua importância na construção da organização familiar e os fenômenos a ele associados. Contudo, nenhuma dessas contribuições se aproxima tanto do que seria o pensamento clínico intersubjetivo quanto as de Donald Winnicott.

\section{1.}

\section{O desenvolvimento a partir do outro}

Segundo Ogden (1986), Winnicott estava ciente do potencial para uma dimensão interpessoal no conceito kleiniano de identificação projetiva, embora ali não houvesse uma referência clara à unidade mãe-bebê, que seria proposta pelo autor. Ele escreve em uma nota de rodapé: “"não existe tal coisa como um lactente', significando, é claro, que sempre que se encontra um lactente se encontra o cuidado materno, e sem o cuidado materno não poderia haver um lactente" (Winnicott, 1960, p.40).

Segundo Ogden (1986), esta unidade é maior que a soma de suas partes, resultando na ideia de que a forma como o ambiente se comporta integra o próprio desenvolvimento infantil. A mãe, em seu estado de preocupação materna 
primária, atua como um ego-auxiliar que é, ao mesmo tempo, objeto e ambiente (Winnicott, 1963b). Ela se permite ser usada pelo bebê e fornece-lhe o continente necessário à integração de suas sensações corporais, estímulos ambientais e suas capacidades motoras nascentes, de acordo com Bleichmar \& Bleichmar (1992). A sensação de continuidade de existência dependeria dessa contenção (holding) suficientemente boa.

Nesse período do desenvolvimento, o objeto é um objeto subjetivo, mágico, que serve ao bebê em todas as suas necessidades; é maleável e se molda àquilo que o lactente precisa, ajudando a sustentar sua ilusão de completude. Em casos graves onde o paciente regride a estados mais primitivos, de acordo com Winnicott (1945), também se pode verificar a presença do objeto subjetivo, que "existe quando desejado, aproxima-se quando nos aproximamos e fere quando o ferimos. Por fim, desaparece quando não mais o desejamos". (Winnicott, 1945, p.228). O objeto serve à necessidade do sujeito, poupando-o das angústias e ansiedades decorrentes da falta.

Ademais, para que o objeto funcione em sua dimensão mágica, na qual a criança tem a ilusão de tê-lo criado, necessita estar presente na realidade objetiva para que seja criado na fantasia. É um "encontrado-criado", como refere Roussillon (2013, p.555), e que nos remete novamente à mãe suficientemente boa, em seu estado de preocupação materna primária. Suficiente porque falha, mas dentro da capacidade de a criança tolerar.

Essas falhas, segundo Winnicott, vão gradualmente desfazendo a sincronia, estabelecida anteriormente na unidade mãe-bebê, fornecendo a dimensão da alteridade e permitindo ao bebê, cada vez mais, tolerar a ausência da mãe. O objeto subjetivo, nessa etapa, em razão da desilusão, ou seja, da gradual indisponibilidade do objeto real frente ao controle mágico exercido pela criança, dá lugar ao objeto transicional: a primeira posse 'não-eu' (Winnicott, 1953). O objeto transicional situa-se em um dos muitos paradoxos estabelecidos na obra de Winnicott, por ser 'eu', 'não-eu', e ao mesmo tempo nenhum dos dois. Habitando esse espaço potencial entre o bebê e a mãe, tornando-se seu representante em sua ausência, mas que na qualidade de representante refere sua ausência.

Até aqui pudemos ver o quanto o self e o objeto mantém íntima relação figurando como indissociáveis no início da vida - e o quanto a relação é essencial aos processos de maturação. Em outras palavras, mesmo sem referi-lo 
diretamente, Winnicott demonstra atribuir importância fundamental ao vínculo ao longo de todo o desenvolvimento, mesmo enquanto ainda não existe, segundo ele, a percepção da alteridade. Vínculo esse, que precisa ser testado e sobreviver aos ataques fantasmáticos, para que haja a emergência do objeto real - integrante de uma realidade compartilhada - com quem o sujeito poderá se vincular.

Para esclarecer que ataques seriam esses, convém acrescentarmos que a agressividade primária, em Winnicott, não é sinônimo de destrutividade, mas de gesto espontâneo e motilidade. Entretanto, diante das frustrações do self frente ao objeto no decorrer do desenvolvimento, é esperado que sejam feitos ataques, sobretudo, na fantasia ao objeto que frustra e que, por isso, é odiado. Segundo Winnicott (1969), nesse momento está em jogo um prolongamento onipotente do mundo interno que pode abranger o objeto externo sob sua esfera de controle, que o autor denominou relação de objeto.

Esse mecanismo faria parte de uma lógica intrapsíquica, em oposição à possibilidade do uso do objeto, que qualificaria verdadeiramente o objeto externo enquanto tal, parte de uma realidade compartilhada sobre a qual a possibilidade de controle é mínima. Segundo Winnicott (1969), a passagem da relação de objeto para o uso de objeto dependeria da sobrevivência deste aos ataques endereçados a ele na fantasia, ou seja, de sua não retaliação e, portanto, de uma não correspondência entre a realidade psíquica e a compartilhada.

Essa diferença entre a realidade psíquica e a realidade compartilhada é o que denunciaria ao sujeito as falhas em sua fantasia onipotente, lançando-o à verdadeira possibilidade de encontro com o objeto, um encontro que se dá pelo reconhecimento da alteridade, e à possibilidade de expressar seu ódio, confiando na sobrevivência do objeto. Por outro lado, caso o objeto reaja com retaliação e, portanto, demonstre ter sucumbido às investidas fantasmáticas da criança, ocorre um reforço da onipotência que fará com que a criança tenha medo de sua própria destrutividade e jamais encontre o objeto em sua alteridade.

Nesses termos, Balint (1968) e Fairbairn (1952) defendiam posições semelhantes à de Winnicott (1969). Se o bebê estabelece, de início, um vínculo de importância vital com um objeto único, e este não suporta a agressividade endereçada a ele e sucumbe, o bebê seria lançado em um desamparo absoluto que, não apenas o privaria da possibilidade de expressar qualquer traço de 
agressividade futuramente, como poderia provocar um recolhimento para o mundo interno pela impossibilidade de confiar no vínculo.

Deste modo, de forma semelhante à que vimos em Balint (1968) e Fairbairn (1952), em Winnicott (1969) a falha precoce no vínculo poderia conduzir aos casos-limítrofes, onde os pacientes se apresentam bastante regredidos subjetivamente. No primeiro desses quadros, uma interpretação possível seria o afloramento defensivo de um falso self, que encapsularia o verdadeiro self de modo a protegê-lo de um ambiente hostil, o que se alinharia, portanto, ao discurso dos demais autores; uma espécie de fechamento em si mesmo decorrente de falhas na vinculação. E no segundo caso, a tendência antissocial, segundo Winnicott (1956), seria uma forma de o sujeito buscar o olhar e a atenção da mãe, de que fora privado precocemente. Em outras palavras, seria um apelo ao vínculo com o objeto-mãe, implicando dificuldades semelhantes às observadas no filobata e no ocnofílico.

Podemos dizer, portanto, que a cada nova contribuição no campo psicanalítico das relações objetais, a importância do vínculo foi tornando-se mais nítida, até o ponto em que, representada na relação entre o sujeito e o ambiente, tomou completamente o centro do debate teórico-clínico, em detrimento da noção de pulsão. Não que houvesse uma negação da pulsionalidade; mas autores como Winnicott (1945) e, em certa medida, Bion (1962) não mais se detinham nela, se interessavam pela relação e seu papel no desenvolvimento psíquico individual.

Nesse mesmo sentido, Bion (1967), em cuja obra a inspiração kleiniana é inegável, apresenta discretas e, por vezes, implícitas menções à pulsão de morte por meio dos comentários sobre a identificação projetiva. Contudo, seu foco estava na teoria sobre o pensamento e, por consequência, nas diferentes formas de vinculação. Assim, tomando por base as contribuições desses autores, psicanalistas como Pichon-Rivière ousaram "questionar as teorias clássicas e incluir o social em um esquema conceitual, referencial e operacional no campo da psicologia social" (Puget, 2015, p.11). Aventuraram-se, portanto, em cruzar as fronteiras do intrapsíquico para pensar os dilemas inconscientes no espaço intersubjetivo. 


\section{2.}

\section{O caráter e o vínculo com o objeto interno}

Pichon-Rivière foi o fundador da Psicologia social na Argentina e aquele que conceituou o vínculo no campo psicanalítico. Segundo ele, que considerava as relações objetais como o último grande passo dado dentro do campo psicanalítico até então, definiu o vínculo como

“... um tipo particular de relação de objeto. Essa relação particular tem como consequência uma conduta mais ou menos fixa com esse objeto, formando um padrão, uma pauta de conduta que tende a se repetir automaticamente tanto na relação interna quanto na relação externa com o objeto" (Pichon-Rivière, 1980, p.17).

Vemos que o autor destaca dois espaços de vinculação: um com os objetos internos e outro com os objetos externos. Contudo, ao invés de situá-los em polos opostos, ou como simples pontos de interesse para diferentes áreas do conhecimento, Pichon-Rivière (1980) preocupou-se em demonstrar a interdependência entre eles. Segundo o autor, o vínculo interno condiciona os aspectos externos e visíveis do sujeito ou, em outras palavras, o caráter. Para o psicanalista, o caráter seria a maneira habitual de o sujeito se comportar, uma expressão de como se relaciona com o objeto interno; "quer dizer, por um vínculo mais ou menos estável e mais ou menos permanente que dá as características do modo de ser do sujeito visto de fora, condicionado por um vínculo interno" (Pichon-Rivière, 1980, p.18). A partir de então, o autor pôde afirmar que a análise do caráter poderia nos levar à forma como o sujeito se relaciona com o seu objeto interno, e que a identificação e observância desta relação, por sua vez, seriam condições necessárias à própria análise do caráter; não há uma sem a outra. Não se trata de procurar pelo objeto interno, mas pela relação que o self estabelece com ele.

Como mencionamos no capítulo anterior, Zimerman (2010) defende que a qualidade dos vínculos internos determinará a qualidade dos vínculos externos estabelecidos ao longo da vida. Há, contudo, uma diferença importante. O autor utilizou tal argumento para justificar sua opção pelo estudo dos vínculos a partir 
da obra de Bion, partindo de uma visão intrapsíquica para pensar o interrelacional. Por outro lado, Pichon-Rivière (1980) postulou que seria através da observação do caráter, ou seja, da análise dos padrões de comportamento em uma relação, que se poderia chegar à relação com o objeto interno, e assim trabalhar o próprio caráter. Enquanto Zimerman pensa o interno para chegar ao externo, Pichon-Rivière propõe pensarmos o externo para que, por meio dele, cheguemos ao interno em uma relação dialética com o externo.

Um exemplo importante dessa perspectiva na obra de Pichon-Rivière (1980) está na situação do tratamento psicanalítico, na forma da diferenciação, feita pelo autor, entre as ideias de autoanálise e heteroanálise. Segundo ele, a autoanálise pressuporia uma espécie de diálogo entre o self e o objeto interno, em que o objetivo seria esclarecer algo sobre o próprio vínculo estabelecido com o objeto, e não sobre o objeto em si. Da mesma forma, o objetivo do que chamou de heteroanálise também seria esclarecer algo acerca do vínculo, mas por meio da relação estabelecida entre o sujeito e o objeto externo, na figura do analista.

Segundo Pichon-Rivière (1980), o processo de análise envolveria a alternância equilibrada entre os dois estados, sendo a sessão presencial o momento da heteroanálise, e os momentos da autoanálise referentes ao antes e ao póssessão. De acordo com o autor, a heteroanálise permitiria internalizar o objeto analista, de modo que imediatamente após uma sessão ou pouco antes da sessão seguinte, a autoanálise se tornaria viável pelo vínculo estabelecido entre o self e o objeto analista internalizado.

De acordo com essa perspectiva, podemos dizer que "quando o paciente está colocado na situação analítica, não sai mais dela" (Pichon-Rivière, 1980, p.20). Isso porque a imagem internalizada do analista e o vínculo particular estabelecido com este permitiriam ao paciente grandes progressos e mudanças, mesmo após o término do tratamento. Essa dinâmica, contudo, não se aplicaria à tentativa de autoanálise de alguém que nunca tenha se submetido ao processo analítico.

Assim, fica ainda mais clara a ideia da dialética entre o externo e o interno, na medida em que o caráter parece ser definido pelo vínculo interno, ao mesmo tempo em que a relação com o objeto externo traz o potencial para alterar a relação com o objeto interno, modificando assim o caráter. Nesse sentido, PichonRivière (1980) declarou que quanto mais regredido o paciente, maior a 
prevalência da vinculação aos objetos internos, seja nos casos de regressão decorrentes do processo de análise ou em casos extremos como o autismo, no qual ocorre um movimento rumo ao mundo interno, ao ponto de o sujeito perder o contato com a realidade.

Tratando mais especificamente das patologias ligadas ao vínculo, PichonRivière (1980), defendeu que, da mesma forma que o autismo, qualquer quadro clínico em saúde mental também poderia ser compreendido em termos de uma vinculação particular com o objeto interno. Como exemplo, o autor propõe que em sintomas esquizofrênicos como o da interceptação de pensamentos, o objeto interno se oporia ao pensamento da mesma forma que, em uma situação externa, uma pessoa poderia opor-se à fala de outra. Segundo ele, nessa mesma linha, as alucinações seriam o resultado da projeção externa de um forte vínculo interno, de modo que aquilo que é visto ou escutado pelo paciente representaria a relação particular de objeto vivida internamente.

Outros exemplos poderiam ser dados nesse sentido, mas chama a atenção a menção ao suicídio feita pelo autor. Pichon-Rivière (1980) afirmou que ao contrário do que se poderia pensar, o fenômeno do suicídio não estaria relacionado a uma situação depressiva, mas a uma dinâmica paranóide. De acordo com o autor, trata-se de uma tentativa de destruir o objeto internalizado, um último recurso na tentativa de controlar dentro de si o objeto interno perseguidor. Segundo Pichon-Rivière (1980), o suicida não exatamente deseja morrer, mas matar seu perseguidor interno, o que torna este ato compatível com a relação de objeto esperada na posição esquizo-paranoide. Nesse sentido, a execução de rituais antes do ato suicida, por vezes demorados, denota uma premeditação e uma tentativa de controle do objeto interno perseguidor que se busca destruir. As automutilações seguiriam o mesmo princípio: uma tentativa "de controle, mutilação e aniquilação do objeto interno colocado no âmbito do corpo" (PichonRivière, 1980, p.24).

Assim, Pichon-Rivière (1980) conclui que:

"A análise do vínculo, o tipo de vínculo e a mutação do vínculo na psicose transformam-se em elementos fundamentais para $o$ prognóstico. Podemos dizer que, na situação transferencial, toda a relação com o objeto interno e as variações que surgirão durante sua projeção sobre o analista irão constituir a base do trabalho concreto e 
diário na psicoterapia do psicótico. Por essa razão é tão importante descobrir o vínculo interno" (p.25-6).

Por meio dessa concepção, o autor defendeu a importância de nos ocuparmos dos vínculos internos, sobretudo, aqueles estabelecidos com objetos maus persecutórios. Isso porque o objeto bom é silencioso, apesar de estar presente, e o vínculo com ele não produz quadros psicopatológicos. Para PichonRivière (1980), a análise do psicótico se tornaria possível exatamente pela possibilidade de se estabelecer uma transferência por intermédio desse objeto bom, o que produziria mudanças na própria psicose, tornando-a uma psicose transferencial, agora capaz de englobar o analista. Aí, então, surgiria a possibilidade de cura.

Segundo Pichon-Rivière (1980), diferentemente do que se defendia na teoria psicanalítica clássica, o analista, diante da psicose transferencial, não poderia manter uma postura de neutralidade, pois passaria a fazer parte do contexto sintomático em que se encontra o paciente. A possibilidade da repetição dos conflitos com o analista na transferência, nesse sentido, permitiria "a ruptura da estrutura psicótica estereotipada", caminho a ser adotado com esses pacientes (Pichon-Rivière, 1980, p.26).

Ao debruçar-se sobre a relação terapêutica, Pichon-Rivière (1980) distingue a ambivalência, situação em que amor e ódio são dirigidos ao objeto total, do que chamou de bivalência, definida pela possibilidade de amor e ódio serem dirigidos a objetos parciais diferentes. Esta última estaria relacionada à posição esquizo-paranóide, orientando o analista, ciente de sua ocorrência, a oferecer interpretações com o objetivo de integrar os "dois elementos do vínculo, bom e mau, dentro e fora do paciente. Na medida em que se possam juntar as partes surge um tipo particular de ansiedade, que é a ansiedade depressiva" (Pichon-Rivière, 1980, p.27). Assim, o autor afirma que tanto o objeto passa a ser, então, amado e odiado pelo paciente, quanto este passa a sentir-se amado e odiado pelo objeto, resultando em um vínculo complexo. 
3.3.

A intersubjetividade na psicanálise vincular

Como pudemos observar, Pichon-Rivière considerou que a vinculação ocorria por meio da internalização do objeto externo e o posterior estabelecimento de um elo com ele. Esse objeto poderia ser algo ou alguém, e só teríamos acesso à vinculação estabelecida entre ele e o sujeito quando esse vínculo fosse expresso por meio da vinculação externa e da transferência. A externalidade poderia trazer novos elementos e modificar o vínculo com o objeto internalizado e este teria o potencial para alterar a forma como o sujeito se relaciona com o mundo externo.

Por outro lado, Puget e Berenstein (1993) propuseram uma visão sobre a vinculação que se afastou ainda mais da psicanálise clássica, definindo o vínculo como uma estrutura relacional entre dois egos, e que, portanto, fugiria ao escopo das relações objetais tratadas sob o viés intrapsíquico. A palavra mais apropriada para descrevê-lo seria, então, o termo "intersubjetivo" - ou, ao menos, essa dimensão precisa ser considerada - por se tratar de um espaço simbólico envolvendo dois egos, fundado nos acordos e pactos inconscientes estabelecidos entre eles. Os acordos seriam os traços convergentes, os quais poderiam ser compartilhados entre as partes, enquanto os pactos seriam os traços divergentes que exigiriam conciliação. Nesse contexto, um vínculo passaria a existir por meio de uma representação interna mútua, ocorrida quando deixamos de ser indiferentes à existência do outro.

Portanto, segundo Puget e Berenstein (1993), os vínculos seriam não somente uma forma de os sujeitos se relacionarem entre si, mas um pressuposto constitutivo da própria subjetividade. Isso porque, de forma semelhante ao que dispôs Winnicott (1960) sobre a relação vital estabelecida na unidade ilusória mãe-bebê, Puget e Berenstein (1993) falam de um vínculo peculiar com o que convencionaram chamar de "objeto único". Segundo eles:

"O vínculo estável com um outro, dotado de caráter de exclusividade e necessidade, a quem ninguém poderia substituir, buscado pelo ego, sem o qual se vê ameaçado pela vivência de aniquilação, dá lugar a esse vínculo peculiar, que chamamos de 'objeto único'. É a primeira organização objetal ainda investida de narcisismo originário. Dela deriva a busca da sensação oceânica e de fusão com esse objeto 
investido, portanto, de qualidades onipotentes, onipresentes $\mathrm{e}$ oniscientes” (Puget \& Berenstein, 1993, p. 138).

Nesse sentido, a mãe estabeleceria com o bebê um vínculo de objeto único, fornecendo-lhe ao continente para as ansiedades de aniquilação e, com isso, permitindo que ela desenvolva essa ilusão de fusão com o objeto que, por meio da fantasia, abrir-lhe-ia as portas para a experiência subjetiva. Todos esses componentes seriam não apenas importantes, mas necessários à própria sobrevivência e à posterior emergência do sujeito, fazendo deste um vínculo dificilmente substituível.

É interessante reparar que, de forma semelhante à própria psicanálise freudiana, Puget e Berenstein (1993) postulam que o modelo de vinculação ao objeto único transforma-se em vínculo estabelecido entre os membros de um casal. Segundo eles, o objeto amoroso é um derivado distante do primeiro, que traz consigo alguns de seus traços como a exclusividade e a sensação de completude, ao mesmo tempo em que se diferencia pela possibilidade de simetria e reciprocidade.

Considerando esses pressupostos, podemos definir a psicanálise vincular como "uma clínica do conjunto, que desenha um inconsciente vincular" (Weissmann, 2011, p.1). Uma modalidade teórico-clínica que busca lidar com as vicissitudes do mal-estar contemporâneo, na qual o vínculo é o próprio objeto de interesse, ao invés das posições subjetivas individuais daqueles que dele fazem parte. Trata-se de nos permitirmos compreender o vínculo familiar, ou de casal, enquanto sendo o próprio paciente, entendendo o adoecimento e o sofrimento dentro dessa perspectiva vincular, considerando os acordos e pactos que ali se desenham. 


\section{4. \\ Estudos de casos}

Optamos, portanto, por estudarmos dois casos clínicos, de modo que pudéssemos reconhecer, analisar e discutir as maneiras pelas quais o fenômeno vincular se coloca durante $\mathrm{o}$ atendimento a famílias em situação de vulnerabilidades.

\section{1. Método}

Realizamos uma pesquisa qualitativa de estudo de casos (Stake, 2010), na qual propusemos análises verticais e uma análise horizontal de dois casos clínicos atendidos semanalmente, em psicoterapia de família, no Serviço de Psicologia Aplicada de uma universidade da região Sudeste do Brasil. Ambos os tratamentos foram interrompidos precocemente por iniciativa das famílias.

\subsection{1. \\ Sujeitos}

Os sujeitos desta pesquisa foram duas famílias em situações diversas de vulnerabilidade, em diferentes configurações. A primeira família, denominada Família 1, apresentou-se ao tratamento composta por quatro membros: mãe (33 anos), pai (38 anos), filho (13 anos) e filha (4 anos), residentes em uma comunidade de baixa renda. A duração do atendimento foi de cinco meses. A segunda, denominada Família 2, apresentou-se sob a forma do subsistema mãefilha, as quais tinham respectivamente 34 e 16 anos e residiam em um bairro de classe média baixa da mesma cidade. A duração do tratamento foi de sete meses.

Os dois casos foram atendidos em coterapia no Serviço de Psicologia Aplicada de uma universidade privada da região Sudeste do Brasil. Durante o trabalho, foram evidenciados muitos conflitos entre os membros em ambas as famílias, as quais eventualmente optaram por interromperem o processo psicoterapêutico, após sucessivas ausências e outras tentativas de quebra do enquadre clínico estabelecido. 
Em relação aos cuidados éticos na apresentação da análise e discussão dos dados, as identidades e determinados conteúdos históricos foram preservados. Portanto, os dados descritos não comprometem o anonimato dos participantes, visando a manutenção do sigilo ético profissional, sem prejuízo à fidedignidade do material clínico. Assim, em observância a todos os preceitos éticos, a pesquisa recebeu aprovação para realização do estudo (número 62/2019), expedida pelo Comitê de Ética em Pesquisa da universidade na qual os casos foram atendidos.

\subsection{2.}

\section{Procedimentos e análise dos dados}

Para o estudo dos casos clínicos, foram utilizados os relatórios produzidos a partir de cada sessão de psicoterapia de família, redigidos à época dos atendimentos pelas duplas de coterapeutas, na forma de um conteúdo majoritariamente descritivo. Os relatórios retrataram a sequência de eventos em cada sessão, dando destaque às temáticas principais discutidas em cada oportunidade, tais como falas e intervenções realizadas. Para realização das análises verticais, foi feita uma leitura flutuante. Posteriormente, foi realizada uma nova leitura fazendo um recorte de conteúdos pertinentes ao estudo, relacionados aos eixos temáticos: modalidades vinculares, repercussões dos vínculos para a fragilização psíquica familiar e expressões das características vinculares no setting terapêutico. Os dados obtidos a partir do material selecionado foram interpretados a partir de uma articulação à luz da Teoria do duplo vínculo (Bateson et al., 1956; Watzlawick et al., 1967) e da Teoria Psicanalítica (Bion 1962; Winnicott, 1963; Pichon-Rivière, 1980).

\subsection{3 Cuidados Éticos}

Por se tratar de uma pesquisa retrospectiva contamos com a assinatura do "Termo de Consentimento Livre e Esclarecido (TCLE)" de todos os integrantes das famílias, à época do atendimento, fazendo parte de um procedimento institucional, no período de triagem do SPA. Os termos foram apresentados e discutidos, em ambos os casos, com todos os membros das famílias, tendo sido esclarecido que havia a possibilidade de alguns dados do tratamento serem 
utilizados para fins de ensino, pesquisa e publicação científica, resguardando todos os aspectos éticos.

O conteúdo dos termos foi discutido no setting, visando a confirmação do entendimento acerca do disposto em texto, oportunidade em que também foi explicitado que a assinatura era voluntária e que tanto o consentimento quanto o assentimento poderiam ser retirados a qualquer tempo, sem qualquer prejuízo ao trabalho psicoterapêutico. $\mathrm{O}$ termo foi assinado pelos responsáveis e o assentimento foi dado, de forma verbal, pelos filhos.

Esse documento, por exigência do Comitê de Ética em Pesquisa da PUCRio, precisou ser complementado por outros dois, redigidos e assinados antes do início desta pesquisa. São eles o "Pedido de Isenção do Termo de Consentimento Livre e Esclarecido (TCLE) e do Termo de Assentimento Livre e Esclarecido (TALE)" e a "Declaração de Anuência do SPA". Ambos os documentos buscaram suprir a impossibilidade de um novo contato com as famílias, que teria por objetivo a atualização do consentimento e do assentimento. Por se tratar de pesquisa retrospectiva, o comitê entendeu, neste caso, ser suficiente um pedido de isenção, preocupado em assegurar todos os cuidados éticos, acompanhado da devida anuência do SPA.

\section{2. \\ Dados Clínicos}

Aqui iniciamos a exposição dos dados pertinentes aos tópicos que desejamos analisar e discutir. Alguns dados dos casos não essenciais foram omitidos ou adaptados com a finalidade de maximizar a preservação do sigilo e a confidencialidade das identidades dos sujeitos.

\subsection{1.}

\section{Histórico da família 1}

Marília e Evaristo se conheceram há 15 anos na porta da casa dela. Ele era cinco anos mais velho e possuía dois filhos do último relacionamento amoroso, enquanto ela, à ocasião de seus dezoito anos, ainda não havia deixado a casa dos pais. Moravam na mesma comunidade desde o nascimento e optaram por permanecerem nela, quando decidiram viver juntos. Dois anos depois, nasceu 
Tomás, que se manteve como filho único por nove anos, ocasião do nascimento de Cristina. A parentalidade trouxe transformações que tornaram a dinâmica conjugal conflitiva.

Evaristo era filho de João e Bettina, que, segundo ele, formavam um casal descontraído em comparação aos pais da esposa, os quais the pareciam sempre muito sérios. Apesar desta descrição aparentemente positiva dos próprios pais, relatou ter presenciado muitas discussões entre eles durante sua infância, incluindo agressões físicas praticadas pelo pai contra sua mãe. João era adicto e ficava alcoolizado com frequência. Na percepção de Evaristo, as marcas daqueles eventos persistiam mesmo após o pedido de desculpas de seu pai, feito há poucos anos.

Marília, por sua vez, embora não tivesse presenciado situações de violência física ou psicológica em sua família de origem, falou do rigor de seus pais e das responsabilidades que tinha desde a infância. Cabia a ela realizar algumas tarefas domésticas e cuidar de primos pequenos na ausência dos respectivos pais, desde muito cedo; atividades que ela executava com louvor e pelas quais costumava ser elogiada. Segundo Marília, isso explicava o incômodo que sentia e a severidade com a qual buscava punir o filho, a quem percebia como um garoto preguiçoso, irresponsável e rebelde.

\subsection{2. \\ Processo terapêutico da família 1}

A família chegou ao Serviço de Psicologia em razão das fugas do filho adolescente que, por vezes, passava dias fora de casa sem dar notícias, a despeito dos esforços de seus pais. Estes preocupavam-se com as amizades de Tomás na comunidade, alegando que alguns amigos eram familiares de traficantes ou, eles mesmos, tinham algum envolvimento com atividades criminosas. Não era incomum que Tomás fosse presenteado por narcotraficantes com bens de consumo, tais como calçados e roupas da moda, ou produtos eletrônicos de última geração. E isso fazia com que os pais se sentissem obrigados a oferecerem ainda mais ao filho, imaginando que desse modo estariam impedindo o adolescente de ser seduzido pelo poder dos criminosos. Tal atitude de submissão os levou a contraírem dívidas e a oferecerem-lhe o sofá (móvel mais confortável da casa), 
enquanto os demais membros da família dormiam em colchas no chão. Estavam engolfados pela ansiedade persecutória da perda do filho e, assim, não negavam nada para o menino; permaneciam reféns desse pavor e, ao mesmo tempo, sentiam muito ódio por tal experiência emocional.

Tomás era, portanto, tratado como um príncipe, embora fosse severamente criticado e punido quando sua atitude refletia o poder conferido a ele, exercido sobre a família. Rejeitava as obrigações e passava horas em ócio, sendo apontado pela mãe como um preguiçoso. Havia sido reprovado na escola por não frequentar as aulas, e mentia sobre suas intenções e seu paradeiro. Era visto regularmente em lugares perigosos, e mantinha comportamentos que lhe conferiam o título de irresponsável pelos pais. Em diversas oportunidades, pernoitava fora de casa após exceder o horário estabelecido por Marília para seu retorno, assim, evitando sofrer os castigos corporais anunciados por ela em suas ameaças. Ela afirmava, por exemplo, que caso o filho não retornasse até o horário marcado, quebrar-lhe-ia as pernas. A resposta do filho era chegar dias depois, assim evitando a punição.

Diante desse quadro, os pais viam-se aterrorizados pela possibilidade de Tomás ser pego em meio a um conflito entre facções criminosas ou entre policiais e traficantes, ou mesmo, pela chance de ser morto por alguma ofensa involuntária feita aos criminosos. Isso fazia com que saíssem à procura do filho pela madrugada, por vezes, colocando-se em situações de risco real. Certa vez, Evaristo contou que adentrou em uma região perigosa sem ser anunciado para "resgatar" o filho adolescente, surpreendendo vários homens armados.

Para Evaristo, o lar era o refúgio que protegia a família de toda a ameaça do mundo externo. Acreditava ser fundamental trazer o adolescente de volta o quanto antes, minimizando assim sua exposição aos perigos. Essa lógica, por sua vez, servia de justificava para que condutas de indiscutível risco também fossem adotadas por parte dos pais, dispostos a sacrifícios heroicos e atitudes extremadas de disciplina, em nome do amor ao filho.

A presença de Tomás na psicoterapia de família, no entanto, trouxe um contraponto, ampliando a compreensão sobre o caso. Segundo o garoto, por diversas vezes ao longo de sua infância, presenciou brigas entre o casal parental, as quais resultavam em agressões físicas do pai contra a mãe. De acordo com o adolescente, a violência só parou à época do nascimento de Cristina, momento em que o pai adotou a estratégia de evadir-se do lar quando enfurecido, retornando 
apenas quando sentia-se mais calmo. Isso significava que, durante nove anos, Evaristo reproduziu a mesma conduta abusiva de seu pai, nas interações com Marília e o filho.

Desde então, Evaristo vinha tentando transmitir a imagem de um pai calmo e assertivo, em oposição a Marília, a quem acusava de ser uma mãe desequilibrada, mas com boas intenções. Ele dizia que era devido aos acontecimentos de sua própria infância que intervinha contra a esposa, quando esta repreendia Tomás. Para ele, o filho poderia se ressentir dela e carregar mágoas por toda a vida, da mesma forma que ele carregava em relação ao próprio pai, algo que gostaria de evitar a todo custo.

Evaristo alegava acredita estar atuando na proteção do filho e da esposa, mas sua intervenção era sentida por ela como violenta, na medida em que a desautorizava diante do filho, e por Tomás como pouco legítima, dado o histórico de agressões físicas antes do nascimento da irmã. Evaristo insistia que a casa era seu refúgio, mas os demais membros da família a percebiam como um "barril de pólvora pronto a explodir". O que se colocava para Tomás era um paradoxo, na forma do dito popular: "se correr o bicho pega, se ficar o bicho come" - expressão utilizada pelos coterapeutas à ocasião, na tentativa de traduzir o mal-estar do menino para o restante da família. Onde seria mais perigoso: em casa ou na rua?

Apesar de o processo psicoterapêutico ter tido a duração total de cinco meses, ao todo foram realizadas apenas sete sessões. $O$ tratamento foi caracterizado por frequentes ausências de todo o grupo e muita irregularidade no comparecimento dos membros da família. Dito de outra forma, todo o processo foi muito instável, não sendo possível prever as configurações de subsistemas que estariam presentes em cada sessão. Havia uma constante sensação de vulnerabilidade do vínculo psicoterapêutico e da continuidade do tratamento, por parte dos coterapeutas.

Após uma sequência de faltas consecutivas, a família concluiu que precisaria interromper o tratamento. Por outro lado, apesar da ausência de toda a família, eles mostraram-se muito gratos pelo atendimento que havia sido realizado até então, sobretudo Marília, que se manifestou de maneira bastante afetiva em sua mensagem final, deixada por meio de um aplicativo de celular. Mas, uma vez foi possível observar o paradoxo da gratidão que só pode ser legitimada, na ausência e à distância. 


\subsection{3.}

\section{Histórico da família 2}

Elvira conheceu o pai de Sabrina quando tinha dezesseis anos, idade da filha à época dos atendimentos, tendo engravidado com dezessete e se tornado mãe assim que alcançou a maioridade. $\mathrm{O}$ casal veio a separar-se em alguns meses. Quatro anos depois da primogênita, Elvira engravidou de outro homem, tendo seu filho caçula: Astro. Segundo ela, ambos os pais de seus filhos eram homens violentos e impulsivos, membros de um mesmo grupo de amigos do qual ela também fazia parte. Em sua versão, eles teriam mantido contato ao longo dos anos e, à época do aniversário de um ano de Astro, entraram com processos judiciais pleiteando a guarda dos filhos.

Ambos os processos foram presumidamente demorados e dolorosos, embora não fosse possível aos coterapeutas notarem qualquer traço de sofrimento no discurso de Elvira. O desfecho do primeiro foi a conquista, pelo pai de Sabrina, da guarda dela, a qual, segundo sua mãe, mentia na escola e nas audiências sobre estar passando fome em casa. O juiz teria entendido o testemunho de Sabrina como um indício de maus tratos ou de negligência por parte de Elvira, conferindo, portanto, a guarda ao pai. Por outro lado, o pai do menino, não obtendo o mesmo sucesso de seu amigo, decidiu sequestrar o próprio filho, tendo cuidado para que onze anos depois, época do tratamento, ainda não houvesse notícias dele ou de Astro.

Nos sete anos que Sabrina morou com seu pai, Rodolfo, um homem a quem se referiu como sendo extremamente rigoroso, vivenciou situações dolorosas. Segundo a menina, quando ele sentia necessidade de corrigir-lhe algum comportamento, fazia com que ela ajoelhasse no milho ou fizesse flexões no chão até sentir-se exausta. Nesse período, viu sua mãe em poucas oportunidades, situações que relatou ter percebido certa "indiferença sádica" de Elvira, frente aos relatos dos castigos administrados por Rodolfo; como se a satisfizesse saber que a convivência da filha com o pai não era fácil.

Aos doze anos de idade, portanto, Sabrina voltou a morar com Elvira, que nessa oportunidade ainda vivia na casa da mãe. Ágata, avó da menina, havia se divorciado alguns anos antes do nascimento de Sabrina e trabalhava como professora. Eram três gerações de mulheres em uma mesma casa, criando uma 
convivência nem sempre agradável, até que Elvira optou por sair e ter sua própria casa.

Contudo, o valor que recebia por seu trabalho de meio expediente era insuficiente para se manterem, o que resultou na necessidade de Ágata de sustentar financeiramente as despesas da filha. Inicialmente o que oferecia era somente um complemento de renda, com o passar do tempo a matriarca passou a pagar todas as despesas. O avô de Sabrina, por sua vez, era ausente desde que se separou de Ágata, não tendo sequer respondido à carta enviada por Elvira avisando sobre o nascimento da neta. Sentiam não poderem contar com ele, nem afetiva e nem financeiramente.

O que Elvira havia conquistado parecia uma espécie de pseudoautonomia: tinha a própria casa para administrar longe das demandas da mãe, mas permanecia completamente dependente financeiramente. Nessa época, Sabrina, que havia se mudado com Elvira, à ocasião do aniversário do sequestro do irmão caçula, fugiu pela primeira vez, tendo passado somente a noite fora de casa. Esse comportamento tornou-se frequente com o passar do tempo, tendo trazido a necessidade de Elvira comunicar o desaparecimento da filha à polícia em diversas oportunidades. Não se tinha notícias por dias ou semanas, até que Sabrina finalmente retornava.

Dois fatos relevantes foram relatados por Sabrina como tendo ocorrido durante seus períodos de ausência. O primeiro referiu-se à situação em que teria sido estuprada por um menino com quem se relacionava, o qual teria insistido para que tivessem relações sexuais e depois seguido com o ato apesar do não consentimento. Ela relatou não ter reagido à violência porque teve um "momento de ausência", o qual, inclusive, levou-a posteriormente a duvidar que aquilo houvesse de fato ocorrido. O segundo, por sua vez, foi uma tentativa de furto, por parte de Sabrina e alguns colegas, a uma loja de conveniência. Nessa oportunidade, ela foi pega em flagrante, fato que deu origem a um processo pelo qual vinha respondendo.

Nesse período turbulento entre as ausências de Sabrina, a menina e sua mãe souberam da morte de Rodolfo pela polícia, em circunstâncias pouco esclarecidas. Elas imaginavam que, pelo envolvimento do mesmo com o tráfico de drogas, ele houvesse sido assassinado por não ter pago suas dívidas. Assim, portanto, além do mistério associado ao sequestro do irmão, havia também o 
paradeiro desconhecido do avô de Sabrina e a morte, ou assassinato, misterioso do pai da menina.

\subsection{4.}

\section{Processo terapêutico da família 2}

O motivo da procura de tratamento foi a necessidade de Elvira de encontrar uma solução para os comportamentos de risco da filha: as fugas de casa, o processo a que respondia e o uso de drogas ilícitas, que acarretava fortes efeitos colaterais pela interação com a medicação psiquiátrica. Apesar de a relação entre as duas ser bastante conflituosa, a mãe era representada de forma idealizada no discurso de Sabrina. Em comparação, a menina sentia-se "burra" por frequentemente perder a conexão com o pensamento sobre o qual falava, característica que a mãe via como indesejável. Aparentemente, o mal-estar gestado nessa família se expressava por meio do comportamento impulsivo e autodestrutivo de Sabrina, que deu início a suas fugas à ocasião do aniversário do desaparecimento do irmão. Ela, por meio do ato impulsivo, mantinha viva a memória do irmão, do qual sua mãe parecia ter desinvestido.

Além disso, logo nas primeiras sessões, chamou atenção as semelhanças entre mãe e filha. Apesar da evidente diferença de idade, ambas se vestiam de maneira muito semelhante e usando adereços idênticos. Tanto Elvira quanto Sabrina usavam o mesmo corte de cabelo. Falavam as mesmas gírias, caminhavam e se portavam da mesma forma; pareciam a mesma pessoa. Certa vez, a mãe apareceu na sessão com um palavrão escrito na cabeça à caneta.

Elvira apresentava muita dificuldade em separar suas memórias das da filha. Mostrava-se confusa, não conseguindo recordar os tempos da gravidez e da primeira infância da filha. Apenas recordou que Sabrina foi muito voraz desde a amamentação; percebia a filha como um bebê insaciável.

Elvira apresentou-se esvaziada de afeto ao mencionar o sequestro do filho caçula - muitas vezes usando palavras como "desaparecimento" e "sumiço" para designar o fato - alegando que tomou todas as medidas cabíveis. Fazia mera referência em tom jornalístico a um processo que tramitava na justiça e a ligações telefônicas feitas aos familiares do pai do menino, nas quais perguntava pelo paradeiro dos dois. 
Também foi possível identificar que as figuras masculinas, dentro da mitologia daquela família feminina, eram retratadas como figuras hostis e ausentes, a exemplo dos pais de Sabrina e Astro, ou nulas como o pai de Elvira, o qual separou-se de Ágata e não manteve contato com esta ou com a filha. Os namorados de Sabrina não eram muito diferentes. A própria menina os comparava a seu pai e aos outros homens com quem sua mãe se relacionou, ainda que esta negasse qualquer semelhança. Por outro lado, se o lugar do masculino parecia desfavorecido, o da mãe foi definido por Elvira como essencial e diferenciado: o de uma amiga que estaria ao lado até que a filha se tornasse capaz de sobreviver sozinha e prover o próprio sustento.

Ao longo do processo de sete meses ocorreram muitas faltas e impedimentos à realização das sessões. Os motivos das ausências variavam caso a caso, e, por vezes, apenas um dos membros da dupla mãe-filha comparecia. Nestes casos, partindo do entendimento de que tratava-se de uma psicoterapia da relação mãe-filha, os coterapeutas estabeleceram que não atenderiam uma sem a outra e sustentaram esse enquadre enquanto durou o trabalho. Em outras palavras, nas oportunidades em que Elvira compareceu sem Sabrina, ou esta sem sua mãe, o atendimento não foi realizado. Como exemplo, por duas vezes, Elvira faltou a sessão de família para cuidar de seus animais de estimação, e em outra ocasião, a falta foi devida à retaliação de Sabrina frente a um castigo dado por sua mãe. Houve momentos de esquecimento e de "defeito" no vale-transporte eletrônico, e aqueles em que a ausência de comunicação fez com que uma viesse e ficasse em casa durante o tempo de sessão, uma aguardando a chegada da outra.

Aqui também observamos uma situação análoga ao duplo vínculo, considerando que a menina, com suas fugas, conseguia deixar o campo. Entretanto, quando se via capturada por esse modelo relacional de "ausências" e "desconexões", era levada a questionar sua própria percepção da realidade, ficando extremamente angustiada, dada a impossibilidade de atender à demanda $\mathrm{e}$ à contrademanda ao mesmo tempo.

Entretanto, com o decorrer do trabalho, Sabrina começou a se expressar e a se autorizar, ainda que timidamente, a falar daquilo que sentia falta em sua mãe, bem como daquilo que lhe causava raiva. Os defeitos da mãe ainda soavam como qualidades, mas antes eram impensáveis ou indizíveis. Elvira, por sua vez, conseguiu admitir para a filha algumas das suas falhas de maternagem, embora 
negasse sentir qualquer culpa, e pôde falar do seu desejo de criá-la. As fugas cessaram por um tempo e, também, o uso de drogas, além do declínio dos comportamentos de risco.

Contudo, após algumas transformações nos padrões vinculares, os atritos em casa voltaram a se intensificar e Sabrina voltou a fugir, resultando no abandono do tratamento pela dupla. Mesmo após a interrupção, Elvira ainda fez alguns contatos, se mostrando agradecida pelos atendimentos realizados.

\section{3.}

\section{Análise e discussão dos dados}

Primeiramente, apresentamos uma análise vertical dos dados, enfocando a discussão sob o prisma da singularidade de cada família e as especificidades dos dois processos terapêuticos. Posteriormente, realizamos uma análise horizontal, tendo como finalidade refletir as semelhanças e diferenças dos padrões vinculares predominantes nas famílias estudadas, buscando pensar os desafios e limites da psicoterapia de família em situações de vulnerabilidade. Optamos por iniciar as análises verticais com apresentação do genograma, a fim de representar tanto a estrutura familiar como a qualidade das relações entre seus membros, de modo a facilitar a identificação e o estudo das questões levantadas no setting (Franco \& Sei, 2015).

\subsection{1.}

\section{Análise vertical da família 1}

O genograma da família 1 (figura 1) ilustra as relações conturbadas entre os membros, à exceção de Cristina. A violência parecia naturalizada na família e isso era percebido pelos coterapeutas, tendo sido relatada e atuada no setting ao longo do tratamento. 


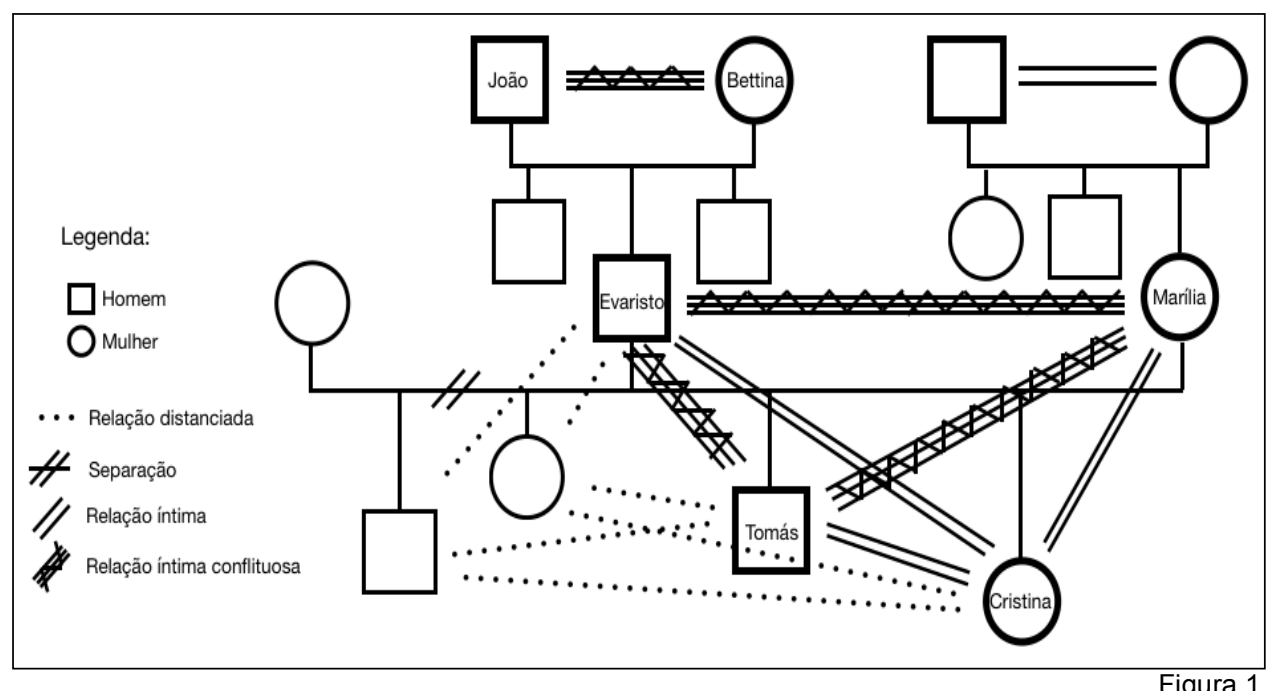

Houve momentos em que foi possível reconhecer a característica "explosiva" dos vínculos no setting, o "barril de pólvora", como a família referiu, a exemplo das agressões de Tomás aos membros do grupo familiar e o silêncio de todos na presença de Evaristo. Nos chamou especial atenção, nesse contexto, os momentos em que o filho bateu bruscamente com a perna no pai e com o braço na mãe, sempre em situações nas quais discordava do que diziam a seu respeito. Em outras oportunidades, o menino dedicava-se a importunar a irmã.

Nas situações de agressão, Tomás não recebia qualquer repreensão, verbal ou física por parte dos pais, que seguiram aparentemente inabalados com suas exposições acerca do filho. Por outro lado, nos momentos em que provocou Cristina, esta respondeu com indignação: revidou os tapas, zangou-se ou saiu de perto do irmão, tendo tido seu comportamento respaldado pela mãe. Nesse sentido, foi observada na situação envolvendo os pais a completa passividade ou ausência de vitalidade do objeto parental. Entendemos essa postura como uma forma de expressão de ódio que não poderia ocorrer de forma direta, implicando o não reconhecimento dos excessos de Tomás enquanto tais. Além disso, a passividade do casal parental também pôde ser percebida como um ataque à demanda de contenção por parte do filho, expressa nos comportamentos agressivos dele. Pensamos que se talvez se essa demanda fosse atendida, poderia oferecer-lhe o reconhecimento de sua existência, acalmando suas ansiedades de aniquilação (Zimerman, 2010).

Além disso, existiram situações em que, enquanto o pai falava, sua esposa e os dois filhos permaneciam em completo silêncio, com o olhar baixo e os 
ombros voltados para frente, em aparente sinal de uma incômoda subserviência. Essa situação não acontecia em sessões, nas quais Evaristo estava ausente; nessas oportunidades todos pareciam ficar mais relaxados.

Ficou compreendido que Tomás, em alguns momentos, não se reconhecia naquilo que os pais diziam sobre ele e, tampouco, no lugar que lhe atribuíam, ponto fundamental do que Zimerman (2010) chamou de Vínculo -R. O menino, portanto, tomado pela angústia derivada desse fracasso do reconhecimento, "gritava" cada vez mais alto - como quem deseja ser ouvido - denotando sua esperança de em algum momento sentir-se percebido em sua singularidade, assim validando sua existência.

Aqui é importante que seja feita a distinção entre os desejos de "ser reconhecido" e de "ser visto". Compreendemos que o menino era visto, e isso justificava que o tratassem como "sua majestade, o bebê" (Freud, 1914), ou que lhe destinassem tanta preocupação e superproteção. No entanto, mesmo sentindose visto, Tomás não parecia sentir-se reconhecido, dada a grande dificuldade na tradução de suas experiências emocionais pelos seus pais. Nesse sentido, pensamos que essa falha na função alfa (Bion, 1962) poderia ser atribuída às projeções das relações de Evaristo e Marília com seus respectivos objetos internos (Pichon-Rivière, 1980). Ao projetarem no filho seus padrões relacionais arcaicos, falhavam em função de tradução e causavam-lhe a angústia do nãoreconhecimento $(-\mathrm{R})$ de sua singularidade.

Nos pais, Tomás encontrava figuras inertes, entretanto, sua irmã esbanjava vitalidade para proteger-se. As reações dela às provocações do irmão poderiam parecer retaliações em um primeiro momento, mas com um olhar cuidadoso notava-se que as consequências desses atos tinham outra função: a de atestar a sobrevivência do objeto (Winnicott, 1969). O incômodo de Cristina provocava risadas no irmão, o qual só continuava a importuná-la caso ela também sorrisse. Se ela não o fizesse, ele ficava visivelmente frustrado, como se estivesse diante da retaliação descrita por Winnicott (1969). No entanto, quando ela sorria estabelecia-se uma linguagem lúdica entre eles, por meio da qual ambos podiam expressar seus ódios sem o medo da fantasia onipotente de destruição do objeto amado. Aqui observamos o vínculo +R (Zimerman, 2010).

Entre os irmãos, tanto o vínculo pelo amor quanto o que se dava pelo ódio também podiam ser considerados em suas formas positivas, $+\mathrm{L}$ e $+\mathrm{H}$, o que 
significa que essas emoções podiam ser expressas de maneira direta, predominantemente, sem a necessidade de formações defensivas (Bion, 1962). Algo semelhante também acontecia entre os pais e a irmã, mas no tocante à relação pai-filho e mãe-filho a vinculação ocorria de maneira diversa e, sobretudo, ambígua. Quando, por exemplo, Marília ameaçava "quebrar as pernas" de Tomás caso este não voltasse no horário combinado, o fazia em nome do amor pelo filho. A partir de Bion (1962), entendemos esta "expressão amorosa" pela via da agressão e hostilidade, como um sinal do ódio enquanto antiemoção (-H), o qual pressupõe um ódio que, não podendo ser expresso como tal, emerge disfarçado de amor.

Em outro exemplo de antiemoção, temos a opção de Evaristo por sair de casa em vista do conflito iminente com a esposa, por quem havia deixado de expressar seu ódio de maneira direta desde o nascimento da filha. Desta forma, ele conseguia preservar a idealização do lar enquanto refúgio, isolando-o em fantasia das ameaças e agressões do exterior. Esse funcionamento nos lembra a dinâmica psíquica esquizo-paranóide descrita por Klein (1946), devido o recurso intenso da cisão dos objetos (lar, comunidade, família) e do self (pai bom x marido violento). Sendo assim, esse exterior ameaçador em realidade, facilmente ficava como depositário das projeções das vivências afetivas violentas de seu próprio mundo interno (Pichon-Rivière, 1980).

Tomás, por sua vez, enxergava o ódio que o pai tentava negar. O adolescente era porta voz da violência projetada, tendo verbalizado nas sessões que, na verdade, a casa era um "barril de pólvora" do qual precisava evadir-se. Desta forma, na medida em que Evaristo tentava proteger o filho contra os males da rua a qualquer preço, e quando fazia elogios à esposa seguidos de críticas implícitas, era possível ver as expressões negativas do amor (-L) e ódio (-H) respectivamente (Bion, 1962).

Identificamos também uma situação análoga ao duplo vínculo (Bateson, 1956) ocorrendo entre os pais e o filho, posto que havia um claro paradoxo entre duas comunicações no nível analógico feitas simultaneamente a Tomás. A primeira dizia-lhe: "peça qualquer bem e lhe daremos. Durma com as melhores acomodações da casa. A você serão permitidas regalias". A segunda, por outro lado, demandava-lhe: "realize o que desejamos, caso contrário podemos atentar contra sua integridade física e psíquica". Nesse sentido, o que fazia a 
comunicação tornar-se paradoxal era a impossibilidade de o menino atender, ao mesmo tempo, as duas informações implícitas: viver como um Rei sem reponsabilidades e viver como funcionário obediente para não ser castigado (Bateson et al., 1956). Caso optasse por viver com regalias e despreocupado, atendia à primeira comunicação, mas falhava na segunda; e se optasse por responsabilizar-se e realizar as tarefas, estaria em conformidade com a segunda, mas fracassaria na primeira.

Chamamos, contudo, essa situação de "análoga ao duplo vínculo" porque, no caso do adolescente, embora estivesse envolvido por essa comunicação paradoxal, ele era capaz escapar do campo adoecedor por meio de suas fugas, movimento este que continha diversas nuances relevantes de serem explicitadas. As fugas, por um lado, permitiam a Tomás evitar a situação duplo-vincular por meio de uma aliança com o objeto mal idealizado e de função compensatória (Fairbairn, 1952), representado na figura dos criminosos, além de denunciar o clima explosivo do ambiente familiar e convocar os pais a ocuparem-se dele, a reconhecê-lo e protegê-lo (Winnicott, 1987). Por outro, passar noites com amigos na praia ou em espaços frequentados por traficantes colocavam-no em situação de risco real, o que denotava componentes autodestrutivos em sua conduta, que aludem a uma relação particular com um objeto interno de contornos possivelmente persecutórios (Pichon-Rivière, 1980).

Ademais, também evidenciamos os ataques ao vínculo (-K), descritos por Bion (1967) sob a forma das dificuldades vividas durante o tratamento, como as faltas sem aviso prévio e as ausências de um ou mais membros da família na maior parte das sessões, bem como a interrupção precoce do trabalho terapêutico. Se considerarmos, como apontam Puget e Berenstein (1993), a família enquanto sujeito da psicanálise de família, então nos seria possível interpretar os ataques ao vínculo como a manifestação dos limites de uma família, como unidade, a conhecer-se a si mesma.

O resultado foi a consequente interrupção do tratamento por parte da família, que por meio da comunicação da mãe com os coterapeutas, demonstrou gratidão por todo o trabalho realizado até ali. Apesar de a psicoterapia ter sido vivenciada, em determinados momentos, como um espaço persecutório, entendemos a manifestação de gratidão da mãe como expressão da internalização de um incipiente objeto bom. Sendo assim, acreditamos que o processo 
terapêutico, como um espaço de escuta e pensar, pode ter despertado algum efeito transformador junto àquele grupo, considerando seus limites e vulnerabilidades psíquicas.

\subsection{2.}

\section{Análise vertical da família 2}

O genograma da família 2 demonstra separações ocorridas em todos os casamentos, o isolamento das mulheres em relação aos homens, e relações íntimas conturbadas entre as três gerações de mulheres.

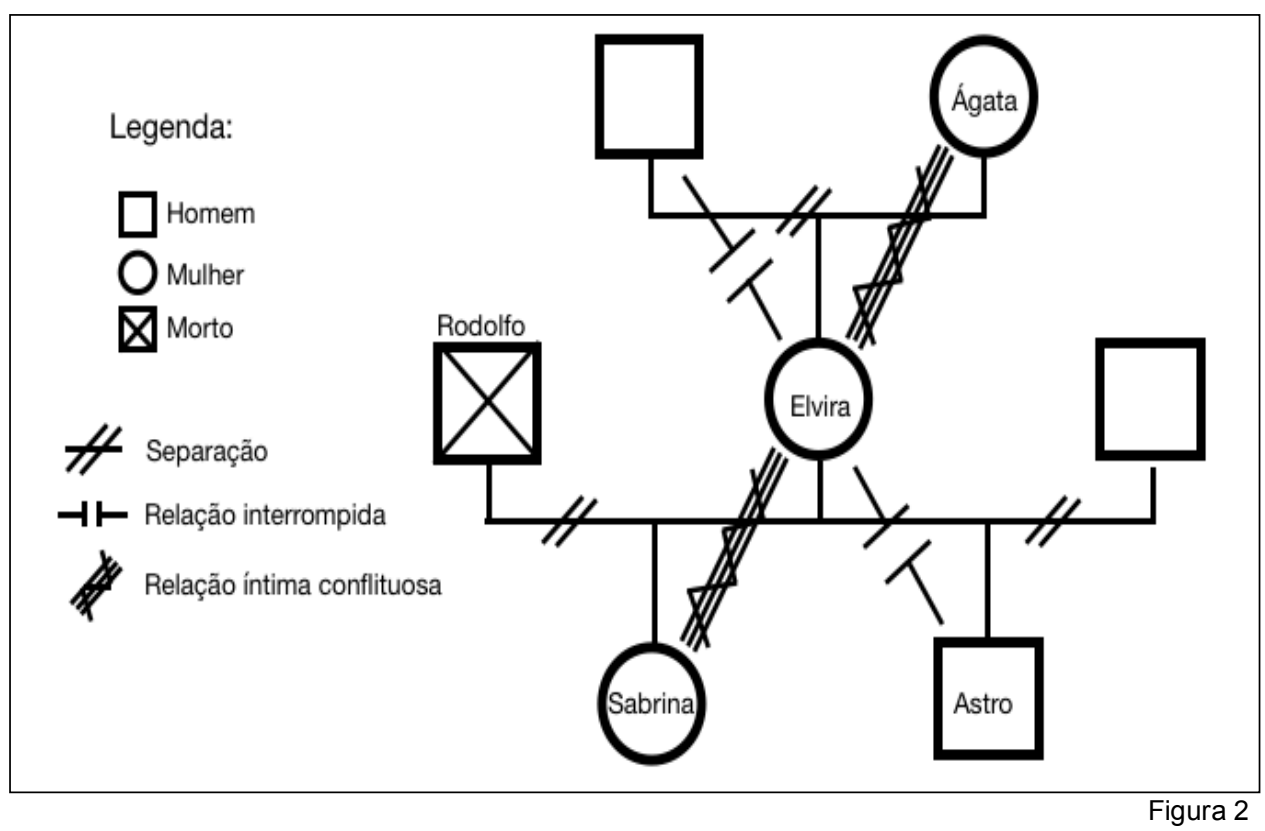

Fica nítida a vulnerabilidade da fronteira geracional entre mãe e filha, devido a horizontalidade entre ambas com comportamentos adolescentes e emaranhados (Magalhães \& Féres-Carneiro, 2015). Como foi mencionado, até as memórias de uma confundiam-se com as da outra, corroborando a hipótese da fusão estabelecida entre mãe e filha, como resultado de uma vinculação baseada na identificação projetiva (Bion, 1967).

Elvira apresentava grandes dificuldades em desenvolver uma vida adulta amadurecida, traço que se manifestava de diversas formas, dentre elas na manutenção da dependência financeira de sua mãe. Morando com Sabrina em um apartamento sustentado por Ágata, Elvira podia viver a experiência de ser adulta sem precisar prescindir do vínculo com a mãe. A permanência da experiência de 
dependência era desejada, apesar de pouco legitimada, sendo sustentada pela ansiedade persecutória da separação com objeto protetor.

Acreditamos que a conquista da independência era vivenciada por Elvira como um risco à integridade dos vínculos, dados os lugares do masculino e do feminino em sua mitologia familiar. Segundo essa tradição, a figura feminina era vista como alicerce da "continuidade de existência de ser" (Winnicott, 1963a), enquanto os homens se distanciam como figuras traidoras e perigosas. Nesse sentido, considerada a crença de Elvira de que a função materna estaria cumprida quando a filha alcançasse a independência, em fantasia representando um alto risco de rompimento do vínculo, assim vivenciando a interdependência como vital e impossível de ser transformada. Pensando nisso, inferimos que Elvira também deveria temer a emancipação da filha, de onde formulamos a hipótese de que ela, por meio da captura da filha, via identificação projetiva e estabelecendo uma relação análoga ao duplo vínculo, procurava manter Sabrina sob seu controle onipotente.

A impossibilidade de pensar e de legitimar todo o sofrimento desencadeado por relações significativas agressivas, vinha sendo mantida por uma situação de funcionamento duplo-vincular, que colocava Sabrina em situação de um aterrador vazio psíquico, hipótese clínica para suas adicções (Stacechen, 2008; Alencar, 2018). Suas percepções eram desmentidas pela mãe com frequência, levando-a a duvidar de seus sentidos e memórias, o que impactava sua dificuldade de expressar o pensamento em palavras (Ferenczi, 1932). Sabrina então, atormentada pela impossibilidade de defender-se das investidas maternas e sentindo-se incapaz de confiar em si mesma, incorria em comportamentos antissociais e autodestrutivos, como forma de reaver a mãe suficientemente boa da primeira infância (Winnicott, 1987).

Observamos também, neste caso, a prevalência das antiemoções entre mãe e filha pela impossibilidade tanto do ódio quanto do amor serem expressos diretamente. As frustrações e os impasses da convivência eram amplificados pela predominância do funcionamento simbiótico entre as duas, resultando na impossibilidade de estabelecer uma relação hierárquica que as diferenciasse, organizando o caos relacional. Assim, o resultado era um enorme desgaste que as impedia a expressão direta do amor (-L), que aparecia apenas por meio de uma idealização cega, ou críticas ditas construtivas, porém severas e cruéis, 
bloqueando a possibilidade de expressão direta do ódio $(-\mathrm{H})$. Negada até não poder ser mais contida, a carga emocional hostil era, então, liberada na forma de agressões físicas e verbais, as quais geravam um enorme sentimento de culpa pela fantasia onipotente de terem destruído o objeto amado (Winnicott, 1969).

Acrescentamos que o vínculo pelo reconhecimento também se apresentava em sua face negativa (-R), dada a fusão entre as duas que as impediam tanto de singularizarem-se quanto de reconhecerem as individualidades uma da outra. E não tão distante, o vínculo pelo conhecimento também se expressava em sua forma negativa (-K), uma vez que conhecer a intrincada configuração vincular gerava perturbações, por vezes, insuportáveis. Estar em tratamento conjunto despertava a desidealização e o ato de pensar compartilhado, problematizando os sintomas e "desfazendo" defesas estabelecidas há anos, que em certa medida parecia despertar angústia.

Sobretudo em Sabrina, mas também observável em Elvira, a relação difícil com o objeto externo parecia revelar uma relação persecutória com o objeto interno, capaz de promover comportamentos autodestrutivos e fantasias de abandono, por vezes, expressas em ato (Pichon-Rivière, 1980). Como no fort-da freudiano (1920), as experiências objetivas e subjetivas de abandono, vividas passivamente, promoviam movimentos defensivos no sentido de abandonar ativamente o objeto por quem o self sentiu-se negligenciado, sustentando a hipótese de ali existir um padrão vincular filobata (Balint, 1968).

A última fuga de Sabrina, de que os coterapeutas tiveram notícia, foi aquela a interromper, em caráter definitivo, a psicoterapia de família. Contudo, levando em consideração os contatos posteriores ao término do trabalho feitos por Elvira, aquela aparente repetição do movimento filobata não era igual às vezes anteriores, posto que a filha vinha se comunicando com maior frequência e de forma menos defendida, denotando uma relação potencialmente menos persecutória com o objeto interno. Por outro lado, ela parecia satisfeita e, apesar da explícita gratidão, não demonstrou interesse em seguir com o tratamento, de onde compreendemos que a psicoterapia havia alcançado sua função, e também a limitação da família quanto ao autoconhecimento que podia, à época, suportar. 
4.3.3.

Análise horizontal

Assim, com o objetivo único de expandirmos nossa compreensão acerca dos atendimentos de famílias em diferentes estados de vulnerabilidade, realizamos esta análise horizontal buscando evidenciar os pontos de aproximação e afastamento observados após as discussões verticais dos dois casos. É importante frisarmos que não tivemos a pretensão de esgotar o tema, mas de abrir uma discussão a ser aprofundada em futuros trabalhos.

Com isso em vista, primeiramente precisamos estabelecer que partimos de uma concepção de vulnerabilidade mais ampla do que a ideia predominantemente difundida, exclusivamente associada às condições de pobreza ou miséria. Nossa perspectiva acolhe a noção de que é possível encontrarmos marcas da experiência de vulnerabilidade, tais como o sentimento de desamparo, as sensações de desproteção e privação, e a precariedade dos vínculos em diferentes seguimentos socioeconômicos (Bauman, 1997, 2001; Birman, 2003; Lipovetsky, 2004). Nesse sentido, entendemos que ambas as famílias podem ser consideradas vulneráveis, apesar das evidentes diferenças entre elas quanto ao poder aquisitivo, ao local de residência e às ocupações de seus membros.

Por outro lado, algo que indubitavelmente as aproximava era a herança transgeracional da violência (Correa, 2000). Ambas as famílias conviviam com as marcas deixadas por experiências de abuso e abandono, as quais pareciam suscitar-lhes terríveis ameaças fantasmáticas de ruptura. Nesse sentido, poderíamos argumentar que, diante da percepção inconsciente de um risco à própria existência dos indivíduos (Fairbairn, 1952), ambas as famílias respondiam com sintomas que visavam proteger os vínculos entre seus membros.

O predomínio de vínculos baseados em antiemoções, por sua vez, pode ser entendido como uma formação reativa à própria impossibilidade de expressão direta das emoções. Isso porque, considerada a perceptível fragilidade das relações a partir da lógica da "relação de objeto" tal como postulada por Winnicott (1969), as fantasias onipotentes de amor e ódio teriam suficiente potencial destrutivo para ferir mortalmente o objeto subjetivamente concebido e, como consequência, o vínculo com ele. Portanto, podemos dizer que havia se estabelecido um vínculo de caráter persecutório com o objeto interno em ambas as 
famílias, marcado pelo medo de retaliações às expressões emocionais diretas percebidas como potencialmente destrutivas (Pichon-Rivière, 1980).

Seguindo essa linha de raciocínio, a prevalência do duplo-vínculo também pode ser analisada segundo a mesma lógica. Uma vez que se tem a perspectiva de um iminente rompimento dos vínculos, a instituição de uma situação duplovincular poderia prestar-se a manter os sujeitos unidos, codependentes. Apesar de os pacientes identificados - Tomás e Sabrina - estabeleceram uma atitude de rejeição da relação com os objetos significativos manifestada pelas fugas e tendências antissociais, paradoxalmente buscavam resgatar o encontro e o olhar dos pais. Entendemos que isso apontava para um desejo latente de reaverem as “mães suficientemente boas" de suas infâncias (Winnicott, 1987), ou a sensação de mistura harmoniosa proporcionada por vínculos seguros (Balint, 1968). Podemos, portanto, pensar os sintomas mencionados acima tanto como denunciadores dos mal-estares vividos nos respectivos contextos grupais, como tendo também a função de defender seus membros contra um mal maior: a separação.

O conflito, em ambos os casos, pareceu corroborar a hipótese de Fairbairn (1952) acerca de a finalidade última da libido ser a formação do vínculo, este sim, responsável por conferir ao sujeito a sensação de existir. Isso porque, por mais conturbados que fossem os arranjos vinculares nas duas dinâmicas familiares que estudamos, a mera possibilidade de seu desgaste ou ruptura parecia promover enorme angústia e intensificar as ansiedades persecutórias nos demais membros. Mesmo que predominantemente caracterizados por antiemoções, os vínculos pareciam ser subjetivamente percebidos como essenciais, e deveriam ser preservados a qualquer custo.

Assim, como consequência natural de nossa reflexão que postulava a sintomatologia familiar como meio primitivo de preservação dos vínculos, finalmente nos perguntamos se as interrupções precoces dos tratamentos também se prestaram ao mesmo fim. Pensamos que sim.

Fundamentamos nossa hipótese na primeira tópica freudiana $(1895 ; 1900)$, onde o autor defendeu a ideia de repressão (ou recalque) como uma força capaz de separar os afetos das representações ligadas a eles, lançando estas últimas ao inconsciente. Esse recurso, no entanto, retiraria da consciência apenas os conteúdos potencialmente nocivos ao bom funcionamento do aparelho psíquico, 
ou seja, condenaria ao esquecimento somente as representações traumáticas para o sujeito. Por sua vez, a repressão não é absoluta, oferecendo oportunidades de retorno do conteúdo reprimido, a exemplo dos sonhos, chistes e atos falhos; situações, por esses motivos, potencialmente enriquecedoras em termos de autoconhecimento.

De maneira complementar, Bion $(1962 ; 1967)$ fala da psicoterapia como uma experiência onde essencialmente atua o vínculo $+K$, aquele que se coloca entre um sujeito que deseja conhecer e um objeto que consente ser conhecido. Por outro lado, $-\mathrm{K}$ surgiria sob a forma de ataques ao vínculo quando, em razão da insuficiência na função alfa, há um retorno dos objetos beta legados ao outro por meio da identificação projetiva, provocando grande angústia no sujeito. Nesse contexto, portanto, $-\mathrm{K}$ teria a função de proteger o sujeito dos perigos associados à experiência de conhecimento, sentido como nocivo, o que pode levar à interrupção da psicoterapia. Isso porque, caso o indivíduo viesse a conhecer seu conteúdo traumático reprimido, sem suficiente tradução e para além de sua capacidade de suportá-lo, correria o risco de sofrer uma cisão ou fragmentação esquizo-paranóide.

De forma similar, tomando a família como sujeito na clínica (Puget \& Berenstein, 1993), o risco de fragmentação oriundo da experiência de conhecimento poderia ser compreendido como uma fantasia de iminente rompimento dos vínculos. Isso posto, tal ameaça também dependeria de o contato com os conteúdos traumáticos exceder a capacidade de a família suportar. Entendemos, portanto, que cada grupo familiar apresentaria uma espécie de limiar de segurança, singular, a partir do qual o conhecimento adquirido passaria a ser percebido, em fantasia, como um risco à integridade dos vínculos, despertando ansiedades de aniquilação (Fairbairn, 1952; Bion, 1967). E esse ponto, segundo Bion (1967), dependeria do quão bem a função alfa pôde ser internalizada pelo sujeito - em nossa hipótese, a família -, influenciando o quanto este permitir-se-á avançar em sua psicoterapia, uma experiência profundamente atravessada pelo conhecimento $(\mathrm{K})$.

Por outro lado, uma maior capacidade de tradução e continência por parte do psicólogo poderia, eventualmente, ampliar as chances de uma família transpor as dificuldades do processo clínico e aprofundar seu tratamento. Sustentamos essa posição a partir de Bion (1962; 1967), considerando o papel do psicoterapeuta 
como representante da função alfa no setting. Naturalmente, contudo, o profissional também poderia tropeçar em suas próprias limitações, fossem de ordem técnica ou emocional, as quais poderemos abordar em futuros desdobramentos deste trabalho.

Isso posto, entendemos que o tratamento, em ambos os casos, alcançou sua função de escuta e de espaço de reflexão. Consideramos as interrupções como naturais representantes das limitações específicas dos encontros singulares entre um grupo familiar e o terapeuta. Neste contexto, portanto, o ataque ao vínculo (K) constituído com o psicólogo no setting teria como objetivo preservar os vínculos entre os membros da família, evitando em fantasia uma fragmentação. 


\section{5. \\ Considerações Finais}

No presente trabalho, tivemos o objetivo de pensarmos alguns dos desafios e limitações da psicoterapia de família, tendo por base a investigação dos padrões vinculares predominantes em famílias em situações de vulnerabilidade; e nos sentimos surpresos pelos rumos que nossas reflexões tomaram. O interesse pela temática vincular nasceu a partir de dois tratamentos de família interrompidos precocemente durante o estágio clínico do pesquisador no decorrer de seu curso de Especialização. Isso porque a discussão dos relatórios das sessões, em supervisão, frequentemente levantava a suspeita de uma possível relação, em ambos os casos, entre os sintomas relatados, a natureza dos vínculos e a resistência à psicoterapia que podíamos observar.

Por sua vez, as interrupções dos dois tratamentos despertaram um mesmo sentimento paradoxal, que trazia simultaneamente as noções de fracasso e de dever cumprido. Como aquilo era possível? O desconforto provocado por esse enigma, associado às suspeitas descritas acima, trouxe-nos a necessidade de nos debruçarmos intensa e sistematicamente sobre os relatórios dos casos, e de aprofundarmos nossos conhecimentos acerca dos vínculos e de suas vicissitudes. Esperávamos com isso ampliar nossa análise sobre os casos e produzirmos compreensões que nos fossem continentes, frente às angústias suscitadas pelo paradoxo. Afinal, os atendimentos foram bem-sucedidos ou fracassados? Acreditamos que nosso processo de investigação também conduziria ao desbloqueio de novos ângulos de observação no campo da psicoterapia de família, ampliando nossas possibilidades de intervenção. Frente aos desafios da clínica, esperamos contribuir para uma prática psicoterapêutica continente e transformadora.

Em nossas explorações teóricas, nos dedicamos primeiramente a alguns pontos básicos da teoria das relações de objeto, campo fundador do pensamento intersubjetivo em psicanálise. Começamos em Klein (1932; 1946) para estabelecermos as bases daquilo que aprofundaríamos em Bion (1962; 1967), autor que não apenas introduziu a noção de vínculo como propôs três diferentes dimensões do fenômeno vincular: a do amor (L), a do ódio (H) e a do conhecimento $(\mathrm{K})$. O vínculo pelo reconhecimento $(\mathrm{R})$, por sua vez, foi uma 
importante adição feita por Zimerman (2010), haja vista o quanto tende a permear e influenciar as relações e as experiências emocionais do indivíduo e da família.

Percorremos também as vicissitudes de falhas relevantes na experiência vincular, passando por autores como Balint (1968), que fala em falsos vínculos e em um narcisismo de contornos defensivos, e Bateson et al. (1956; 1964), que desenvolvem a ideia de duplo-vínculo. Diante desses sintomas tão graves e desafiadores, sentimos a necessidade de nos indagarmos acerca da real necessidade de vinculação por parte do sujeito, e encontramos respostas interessantes em diversos autores. Vimos na própria teoria balintiana o quanto era importante o (re)estabelecimento de uma sensação de mistura harmoniosa, que encontra paralelos com a noção winnicottiana de unidade mãe-bebê. Mas, sobretudo, vimos em Fairbairn (1952) a ideia de que o vínculo seria a verdadeira finalidade da libido, sendo responsável por conferir ao sujeito a sensação de existência.

Em seguida, nos debruçamos sobre algumas noções, em Winnicott (1945; $1960 ; 1963$; 1987), que complementam e corroboram as teorias de Bion, Balint e Fairbairn, bem como semeiam o terreno para que Pichon-Rivière (1980) desenvolva importantes contribuições. Segundo o autor, o vínculo seria uma forma particular de relação de objeto, uma relação com o objeto externo que permite lançar luz sobre a relação com o objeto interno. Seria, por sua vez, essa última a responsável pela consolidação do caráter tanto quanto um meio para transformá-lo. E, por último, abordamos a ideia de a família ser o sujeito na psicoterapia, proposta por Puget e Berenstein (1993), que nos permitiu traçarmos paralelos entre o funcionamento psíquico do indivíduo e do grupo familiar.

Em seguida, nos dedicamos ao estudo e exposição dos pontos nodais dos casos clínicos aos quais nos referimos anteriormente, e notamos que, em ambos os casos, havia a prevalência de antiemoções associadas a situações duplo-vinculares e uma baixa "tolerância ao conhecimento". Isso nos fez indagar se essas características poderiam ser inerentes à condição de vulnerabilidade em sentido amplo, mas precisaríamos de mais investigações nesse sentido para que pudéssemos atestar ou refutar essa hipótese. No entanto, pudemos verificar que o processo psicoterapêutico suscitou uma incipiente capacidade de os sujeitos praticarem a autoanálise (Pichon-Rivière, 1980), ou seja, de questionarem-se a si mesmos sobre alguns padrões de comportamentos e experiências emocionais que, 
agora, conseguiam estranhar. Além disso, puderam identificar que uma parte relevante dos conflitos que experimentavam tinha origem em modelos vinculares anteriores, transgeracionais, e que sua repetição lhes dificultava o acesso às próprias experiências emocionais, produzindo comportamentos e comunicações paradoxais.

A situação de vulnerabilidade experimentada, em diferentes níveis, pelas duas famílias foi um desafio, principalmente para a manutenção do tratamento, posto que trazia para o setting a experiência da ambiguidade, característica predominante da dinâmica familiar que estabeleciam. Por um lado, as famílias pareciam ter esperança de que a psicoterapia de família as ajudaria, algo que pudemos inferir a partir da adesão ao tratamento e do bom relacionamento estabelecido com os coterapeutas. Por outro, os ataques ao vínculo (-K), nas formas de frequentes faltas e quebras de enquadre, denunciavam a proximidade do limiar de segurança responsável pela preservação dos vínculos frente à fantasia de aniquilação despertada pelo conhecimento.

Os coterapeutas lidaram com esse paradoxo por meio de suas capacidades de rêverie, procurando traduzir as comunicações analógicas de maneira que as experiências emocionais invertidas, disfarçadas e não legitimadas pudessem emergir, serem comunicadas e pensadas. Assim, criou-se a possibilidade de as famílias ampliarem levemente seus limiares de segurança, permitindo-se aumentarem proporcionalmente seu acesso ao conhecimento e melhorando a absorção (internalização) do objeto-analista (Pichon-Rivière, 1980). Acreditamos, portanto, que a escolha pela interrupção do tratamento estivesse intimamente relacionada à proximidade do ponto, a partir do qual o autoconhecimento provocava o afloramento de suas ansiedades de aniquilação.

Entendemos que o fracasso ao qual nos referimos no início deste capítulo e no título deste trabalho não encontrou sustentação nos fatos analisados no presente texto. Isso porque identificamos que o tratamento permitiu às famílias ampliarem seu autoconhecimento tanto quanto lhes foi possível, observando seus respectivos limiares de segurança. O sentimento de fracasso, por sua vez, nos pareceu um desdobramento natural de um tratamento atravessado por ataques ao vínculo e identificações projetivas, vivenciados pelos coterapeutas de maneira persecutória. Pensamos que, diante das dificuldades vivenciadas no trabalho clínico, os coterapeutas, representantes da função alfa no setting, podem ter se 
sentido frustrados, insuficientes e impotentes frente ao baixo limiar de segurança observado nas famílias. Essa seria, portanto, nossa hipótese para o surgimento do sentimento de fracasso por parte dos coterapeutas.

Constatamos, portanto, que não podemos negligenciar o lugar do psicoterapeuta frente aos desafios vivenciados na clínica, uma vez que ele pode ter grande influência na elasticidade da tolerância da família ao autoconhecimento. Por fazer parte do setting, ocupando um lugar de grande relevância e destaque, o profissional se vê frequentemente atravessado e afetado pelos vínculos e padrões de vinculação da família que atende. Está sujeito a experimentar sentimentos e sensações que podem auxiliar ou obstruir sua escuta. É nessa linha que pretendemos caminhar em futuros trabalhos, procurando aprofundarmos nossa compreensão sobre a relação entre o profissional, a família e o limiar de segurança relativo ao conhecimento. Acreditamos que, assim, poderemos seguir contribuindo para a ampliação do potencial transformador da psicoterapia. 
6.

\section{Referências}

Alencar, R. (2018). Fome da Alma: psicanálise, drogas e pulsão na modernidade. São Paulo: Benjamin Editorial.

Ávila, N. (2016). Indivíduos, vínculos, relações: da sensação à reação - alterando movimentos e expressividades do corpo. Revista científica on-line Tecnologia - gestão - humanismo, 6(1). Recuperado em 29 de Novembro de 2019, de http://www.fatecguaratingueta.edu.br/revista /index.php/RCOTGH/article/view/133/155

Balint, M. (2014). A falha básica: aspectos terapêuticos da regressão. - $2^{\mathrm{a}}$ ed. São Paulo: Zigodoni. (Publicação original em 1968).

Bateson, G., Jackson, D., Haley, J. \& Weakland, J. (1956) Towards a theory of schizophrenia. Behavioural Science, 1(4), 251-254. Recuperado em 25 de Novembro de 2019, de https://solutions-centre.org/pdf/TOWARD-ATHEORY-OF-SCHIZOPHRENIA-2.pdf

Bateson, G. \& Jackson, D. (1964) Disorders of comunication. Vol. 42. Baltimore: Research Publications.

Bauman, Z. (1997). O Mal-estar da pós-modernidade. Rio de Janeiro: Zahar.

Bauman, Z. (2001). Modernidade líquida. Rio de Janeiro: Zahar.

Bion, W. R. (1966). O aprender com a experiência. Rio de Janeiro: Zahar. (Publicação original em 1962).

Bion, W. R. (1988). Estudos psicanalíticos revisados. Rio de Janeiro: Imago. (Publicação original em 1967).

Birman, J. (2003) Mal-estar na atualidade: a psicanálise e as novas formas de subjetivação. - $4^{\mathrm{a}}$ ed. - Rio de Janeiro: Civilização Brasileira.

Bleichmar, N. \& Bleichmar, C. (1992). A psicanálise depois de Freud: teoria e clínica. Porto Alegre: Artes Médicas. (Publicação original em 1989).

Braga, J. C. (2017). O legado de Bion: um novo paradigma para pensar a psicanálise. Jornal de Psicanálise, 50(92), 180-193. Recuperado em 01 de dezembro de 2019, de http://pepsic.bvsalud.org/scielo.php?script=sci _arttext\&pid=S0103-58352017000100014\&lng $=$ pt\&tlng $=$ pt.

Broide, J. (2010). Psicanálise nas situações sociais críticas: violência, juventude e periferia em uma abordagem grupal. Curitiba, PR: Juruá Editora

Celes, L. A., Santos, A. C., \& Alves, K. C. (2006). Teoria das relações de objeto em Freud e Fairbairn. Mal Estar e Subjetividade, 6 (2), 291-310,. 
Elkaïn, M. (1990). Se você me ama, não me ame: abordagem sistêmica em psicoterapia familiar e conjugal. Campinas: Papirus. (Publicação original em 1989).

Fairbairn, R. (1980). Estudos psicanalíticos da personalidade. Rio de Janeiro: Interamericana. (Publicação original em 1952).

Ferenczi, S. (1992). Reflexões sobre o trauma. In: S. Ferenczi. Obras completas de Sandor Ferenczi, vol. IV. São Paulo: Martins Fontes. (Publicação original em 1932).

Franco, R. \& Sei, M. (2015). O uso do genograma na psicoterapia psicanalítica familiar. Revista interinstitucional de psicologia, 8(2), 399-414. Recuperado em 01 de dezembro de 2019, de http://pepsic.bvsalud.org /pdf/ gerais/v8n2/v8n2a09.pdf

Freud, S. (2006a). Sobre o mecanismo psíquico dos fenômenos histéricos: uma conferência. In: Freud, S; Obras completas, ESB, vol. III. Rio de Janeiro: Imago. (Publicação original em 1893).

Freud, S. (2006b). A interpretação dos sonhos. In: S. Freud. Obras completas, $E S B$, vol. VI. Rio de Janeiro: Imago. (Publicação original em 1900).

Freud, S. (2006c). Sobre o narcisismo: uma introdução. In: S. Freud. Obras completas, ESB, vol. XIV. Rio de Janeiro: Imago. (Publicação original em 1914).

Freud, S. (2010a). Estudos sobre a histeria. In: S. Freud. Obras completas. vol. II. São Paulo: Companhia das Letras. (Publicação original em 1895).

Freud, S. (2010b). Além do princípio do prazer. In: S. Freud. Obras completas. vol XIV. São Paulo: Companhia das Letras. (Publicação original em 1920).

Gay, P. (2012). Freud: uma vida para nosso tempo. São Paulo: Companhia das Letras.

Guimarães, F. L., Diniz, G. R. S., \& Angelim, F. R. (2017). "Mas Ele Diz que me Ama...": Duplo-Vínculo e Nomeação da Violência Conjugal. Psicologia: Teoria e Pesquisa, 33, 1-10. Recuperado em 01 de dezembro de 2019, de http://www.scielo.br/pdf/ptp/v33/1806-3446-ptp-33-e3346.pdf

Klein, M. (1997) Psicanálise de crianças. Rio de Janeiro: Imago. (Publicação original em 1932).

Klein, M. (1991). Inveja e gratidão e outros trabalhos. Rio de Janeiro: Imago,. (Publicação original em 1946).

Lipovetsky, G. (2004). O império do efêmero: a moda e seu destino nas sociedades modernas. São Paulo: Companhia das letras. (Publicação original em 1987).

Magalhães, A.S. \& Féres-Carneiro, T. (2015) The house of seven women: the 
fading of generational boundaries in the Family. Couple and Family Psychoanalysis, 5, 89-97.

Mello, R. \& Herzog, R. (2008). Subjetividade e defesa na obra de Michael Balint. Mal Estar e Subjetividade, 8 (4), 1121-1142.

Nunes, G. \& Peixoto Junior, C. (2019). A experiência esquizoide segundo Fairbairn e Guntrip. Ágora: Estudos em Teoria Psicanalítica, 22(1), 75-86.

Ogden, T. (2017). A matriz da mente: relações objetais e diálogo psicanalítico. São Paulo: Blucher. (Publicação original em 1986).

Peixoto Junior, C. (2004) As relações objetais primárias no contexto da falha básica. Natureza Humana, 6(2): 235-253.

Pichon-Rivière, E. (2007). Teoria do vínculo. São Paulo: Martins Fontes. (Publicação original em 1980).

Puget, J. (2015) Subjetivación discontínua y psicoanálisis: Incertidumbre y certezas. Buenos Aires: Lugar Editorial.

Puget, J. \& Berenstein, I. (1993). Psicanálise do casal. Porto Alegre: Artes Médicas.

Roussillon, R. (2013). A destrutividade e as formas complexas da sobrevivência do objeto. Psicanálise, 14(2): 553-572.

Segal, H. (1975). Introdução à obra de Melanie Klein. Rio de Janeiro: Imago. (Publicação original em 1964).

Stacechen, L.; Bento, V. (2008). Consumo excessivo e adicção na pósmodernidade: uma interpretação psicanalítica. Fractal Rev. de Psicologia, v. 20, n. 2, p. 421-435. Recuperado em 01 de dezembro de 2019, de http://www.scielo.br/scielo.php?script=sci_arttext\&pid=S198 4-02922008 000200009\&lng=en\&nrm=iso.

Stake, R. E. (2010). Investigación con estudio de casos. Madri: Ediciones Morata.

Watzlawick, P. Beavin, J. Jackson, D. (2007). Pragmática da comunicação humana. São paulo: Pensamento-Cultrix. (Publicação original em 1967).

Weissman, L. (2011). Psicanálise das configurações vinculares. Notícias do campo psicanalítico, V. 18. Recuperado em 20 de dezembro de 2019, de http://www.sedes.org.br/Departamentos/Psicanalise/index.php?apg=b_visor\& $\mathrm{pub}=18 \&$ ordem $=16$

Winnicott, D. W. (1975a). Objetos transicionais e fenômenos transicionais. In: D. W. Winnicott. $O$ brincar e a realidade. Rio de Janeiro: Imago. (Publicação original em 1953). 
Winnicott, D. W. (1975b). O papel de espelho da mãe e da família no desenvolvimento infantil. In: D. W. Winnicott. O brincar e a realidade. Rio de Janeiro: Imago. (Publicação original em 1967).

Winnicott, D. W. (1975c). O uso de um objeto e relacionamento através de identificações. In: D. W. Winnicott. $O$ brincar e a realidade. Rio de Janeiro: Imago. (Publicação original em 1969).

Winnicott, D. W. (1983a). Teoria do relacionamento paterno-infantil. In: D. W. Winnicott. $O$ ambiente e os processos de maturação: estudos sobre a teoria do desenvolvimento emocional. Porto Alegre: Artmed. (Publicação original em 1960).

Winnicott, D. W. (1983b). Da dependência à independência no desenvolvimento do indivíduo. In: D. W. Winnicott. O ambiente e os processos de maturação: estudos sobre a teoria do desenvolvimento emocional. Porto Alegre: Artmed. (Publicação original em 1963a).

Winnicott, D. W. (1983c). O desenvolvimento da capacidade de se preocupar. In: D. W. Winnicott. $O$ ambiente e os processos de maturação: estudos sobre a teoria do desenvolvimento emocional. Porto Alegre: Artmed. (Publicação original em 1963b).

Winnicott, D. W. (2000). Desenvolvimento emocional primitivo. In: D. W. Winnicott. Da pediatria à psicanálise: obras escolhidas. Rio de Janeiro: Imago, 2000. (Publicação original em 1945).

Winnicott, D. W. (2002). Privação e delinquência. São Paulo: Martins Fontes. (Publicação original em 1987).

Zimerman, D. (2010) Os quatro vínculos: amor, ódio, conhecimento, reconhecimento na psicanálise e em nossas vidas. Porto Alegre: Artmed. 
7.

\section{Anexo 1}

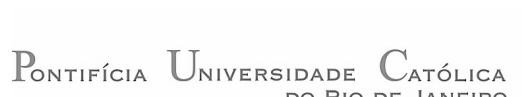

TERMO DE CONSENTIMENTO DO SPA - Serviço de Psicologia Aplicada PUC-Rio

$\mathrm{Eu}$, , abaixo

assinado(a), paciente em avaliação e/ou atendimento no Serviço de Psicologia Aplicada da PUC-Rio (Rua Marquês de São Vicente, 225 - Gávea, CEP: 22453-900, telefone (21) 3527-1573 / 75, ou e-mail psispa@puc-rio.br), tendo sido informado(a) a respeito do caráter de ensino e pesquisa desta instituição, concordo com a possibilidade dos meus dados serem utilizados para fins de ensino, pesquisa e publicação científica, resguardados todos os aspectos éticos. É de meu conhecimento, também, que todas as informações fornecidas serão mantidas em absoluto sigilo, não podendo ser usadas para nenhuma outra finalidade.

Rio de Janeiro, de de

Assinatura do (a) Paciente 
8.

Anexo 2

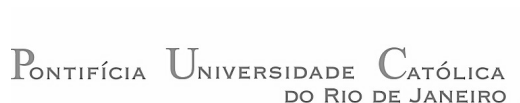

Declaração de anuência do SPA - Serviço de Psicologia Aplicada PUC-Rio

Eu, Helenice Charchat, diretora do Serviço de Psicologia Aplicada (SPA) da PUC-Rio, subscrevo o pedido de isenção do Termo de Consentimento Livre e Esclarecido (TCLE) e do Termo de Assentimento Livre e Esclarecido (TALE) feito pelo pesquisador Rodrigo Nunes de Souza Trindade e sua professora orientadora Rebeca Nonato Machado, referente à pesquisa intitulada “Adoecimento Psíquico e a Família: Estudo de casos”. Acredito que com o referido documento e a assinatura do termo institucional do SPA à ocasião dos atendimentos, estejam resguardados os aspectos éticos do trabalho.

Rio de Janeiro, de de

Diretora do SPA 
9.

Anexo 3

\section{Pedido de Isenção do Termo de Consentimento Livre e Esclarecido (TCLE) e do Termo de Assentimento Livre e Esclarecido (TALE)}

Solicito a isenção da aplicação do Termo de Consentimento Livre e Esclarecido e do Termo de Assentimento Livre e Esclarecido do projeto de pesquisa intitulado "Adoecimento Psíquico e a Família: Estudo de casos" com a justificativa de: Tratar-se de pesquisa clínica retrospectiva com base em relatórios de atendimentos realizados pelo pesquisador, referentes às sessões de psicoterapia de família ocorridas no Serviço de Psicologia Aplicada (SPA) da PUC-Rio em 2017. Considerando o fim do tratamento, há grande dificuldade de acesso a todos os membros das famílias abordadas. Acrescento que, à ocasião, os responsáveis da família assinaram voluntariamente o termo utilizado na instituição, o qual prevê a possibilidade de os dados serem utilizados para fins de ensino, pesquisa e publicação. $\mathrm{O}$ assentimento foi dado, de forma verbal, pelos filhos e demais membros.

\section{Declaro:}

a) Que o acesso aos dados registrados em relatórios de sessões clínicas, para fins da pesquisa científica, será feito somente após aprovação do projeto de pesquisa pelo Comitê de Ética;

b) Assegurar o compromisso com a privacidade e a confidencialidade dos dados utilizados, preservando integralmente o anonimato e a imagem do sujeito, bem como a sua não estigmatização.

c) Assegurar a não utilização das informações em prejuízo das pessoas e/ou das comunidades, inclusive em termos de autoestima, de prestígio e/ou econômico-financeiro;

d) Que os dados obtidos na pesquisa somente serão utilizados para o projeto vinculado;

e) Que os relatórios e o arquivamento dos dados foram preservados aos cuidados somente do pesquisador e da orientadora/supervisora, em computador com senha.

Devido à impossibilidade de obtenção da assinatura de todos os sujeitos, após o tratamento, do TCLE (Termo de Consentimento Livre Esclarecido) e do TALE (Termo de Assentimento Livre e Esclarecido) específicos do projeto, assino este termo para salvaguardar seus direitos de confidencialidade das informações e anonimato das identidades.

Pesquisador responsável

Orientadora

Rio de Janeiro 28 de Junho de 2019. 